\title{
CEsifo WORKING

\section{Corporate Profit Shifting and the Role of Tax Havens: Evidence from German Country-By-Country Reporting Data}

Clemens Fuest, Felix Hugger, Florian Neumeier 


\section{Impressum:}

CESifo Working Papers

ISSN 2364-1428 (electronic version)

Publisher and distributor: Munich Society for the Promotion of Economic Research - CESifo

$\mathrm{GmbH}$

The international platform of Ludwigs-Maximilians University's Center for Economic Studies and the ifo Institute

Poschingerstr. 5, 81679 Munich, Germany

Telephone +49 (0)89 2180-2740, Telefax+49 (0)89 2180-17845, email office@cesifo.de

Editor: Clemens Fuest

https://www.cesifo.org/en/wp

An electronic version of the paper may be downloaded

- from the SSRN website: www.SSRN.com

- from the RePEc website: $\quad$ www.RePEc.org

- from the CESifo website: https://www.cesifo.org/en/wp 


\title{
Corporate Profit Shifting and the Role of Tax Havens: Evidence from German Country-By-Country Reporting Data
}

\begin{abstract}
This paper is the first to use information from individual country-by-country (CbC) re-ports to assess the extent of profit shifting by multinational enterprises. Unlike other data often used to evaluate the extent of profit shifting and tax avoidance, $\mathrm{CbC}$ reports pro-vide a complete coverage of the global distribution of profits and indicators of economic activity for multinationals exceeding a certain revenue threshold. We show that $82 \%$ of the German multinationals subject to $\mathrm{CbC}$ reporting have tax haven subsidiaries and that these subsidiaries are notably more profitable than those in non-havens. However, only $9 \%$ of the global profits of German multinationals are reported in tax havens. Results from regression analysis suggest that approximately $40 \%$ of the profits reported in tax havens are a result of tax-induced profit shifting. The associated annual tax base loss for Germany amounts to EUR 5.4 billion. Adding estimates of profit shifting by multinationals not covered by the CbC data yields an overall estimate for profits shifted out of Germany to tax havens of EUR 19.1 billion per year, corresponding to 4.3\% of the profits reported by these firms in Germany. This implies a tax revenue loss due to corporate profit shifting to tax havens of EUR 5.7 billion per year.
\end{abstract}

JEL-Codes: F230, H250, H260.

Keywords: corporate taxation, tax avoidance, profit shifting, multinational enterprises, countryby-country reporting.

Clemens Fuest

ifo Institute - Leibniz Institute for Economic Research at the University of Munich / Germany fuest@ifo.de
Felix Hugger

University of Munich / Germany

felix.hugger@econ.lmu.de

Florian Neumeier

ifo Institute - Leibniz Institute for Economic Research

at the University of Munich / Germany

neumeier@ifo.de

January 8, 2021

This research includes work undertaken on behalf of and financed by the German Federal Ministry of Finance. However, this work should not be construed to represent the Ministry's position or that of any of its staff members. The work was done independently by the authors and on their own responsibility. The views expressed in this paper are thus those of the authors. We thank Michelle Hanlon, James Hines, Rebecca Lester, Andreas Peichl, Dominik Sachs, Juan Carlos Suárez Serrato, participants of the NBER workshop on 'Business Taxation in a Federal System' and a workshop organized by the Center for Economic Studies in Munich for helpful comments on earlier versions of this paper. The usual disclaimer applies. 


\section{Introduction}

Tax avoidance and profit shifting activities by multinational enterprises (MNEs) trigger heated public debates. There is a widespread view that MNEs shift a large proportion of their profits to low-tax countries or 'tax havens' so that they do not pay their fair share in high-tax countries where they produce and sell most of their products. There is a growing body of academic research supporting this view by showing that MNEs' activities in low-tax countries are far more profitable than their activities in high-tax countries or than those of local firms. However, empirical work on international corporate tax avoidance suffers from severe data limitations, mostly due to a lack of information about MNEs' activities in tax havens.

This paper investigates profit shifting using new data from country-by-country (CbC) reports filed by large German MNEs. These reports provide complete coverage of the global distribution of their profits, sales, employees, fixed assets, and other variables. They also include data on cross-border transactions within multinational groups, which are important instruments for profit shifting. CbC reporting has been introduced in the context of the OECD/G20 Base Erosion and Profit Shifting (BEPS) project. ${ }^{1}$ In Germany, a CbC reporting obligation was introduced in 2016 .

The main results of our analysis are as follows. First, we find that $82 \%$ of the German MNEs in our sample have subsidiaries in tax havens. ${ }^{2}$ These subsidiaries are much more profitable than those in non-haven countries. The share of profits reported in tax havens is not very large though - just $9 \%$ of global profits. At the same time, only $4 \%$ of German MNEs' tangible assets and $3 \%$ of their employees are located in tax havens. Of the tax haven profits, $87 \%$ are reported in European tax havens like Switzerland, Ireland, and the Netherlands. Tax havens outside Europe such as Bermuda, the British Virgin Islands, or the Cayman Islands only play a minor role. Second, we estimate that tax-induced profit shifting by large German MNEs increases the profits they report in tax havens by EUR 9 billion per year. This is roughly equal to $3 \%$ of their worldwide profits, and less than the amount of profit shifting found in other recent studies. For instance, Zucman (2014) estimates that US MNEs shift almost 20\% of their profits to tax havens; Tørsløv et al. (2018) estimate that globally, $40 \%$ of the profits MNEs report outside their country of residence are shifted to tax havens.

\footnotetext{
${ }^{1} \mathrm{CbC}$ reporting is mandatory for MNEs with consolidated revenues of at least EUR 750 million and whose headquarters are located in one of the 90 member countries of the Inclusive Framework on BEPS that introduced a corresponding filing obligation into national legislation (see Section 2 for details).

${ }^{2}$ Gumpert et al. (2016) use data from the German Bundesbank on foreign subsidiaries of German MNEs and find that only $20 \%$ of all German MNEs have a tax haven presence. This discrepancy is most likely due to differences in the samples. The data of Gumpert et al. (2016) covers a much larger fraction of German MNEs as the size threshold for inclusion in the Bundesbank sample is much lower. Moreover, their sample covers the years from 2002 to 2008, while our data is for 2016 and 2017. For the US, Desai et al. (2006) report that 59\% of US MNEs have tax haven subsidiaries.
} 
Third, findings from regression analyses show that profits as well as intra-firm revenues reported by large German MNEs in a country are sensitive to effective average tax rates. In our baseline specification, we identify a semi-elasticity of profits with respect to differences in the effective average tax rate of -0.5 and a tax semi-elasticity of intra-firm revenues of -1.3 . In contrast, differences in standard ('headline') statutory tax rates do not seem to play a role. We attribute this finding to the fact that nowadays, tax competition between countries mainly takes place through instruments other than statutory tax rates, such as R\&D tax subsidies, patent boxes, and tax exemptions. As a result, statutory tax rates are an imperfect measure of the actual tax burden. Moreover, our regression results confirm that profit shifting by large German MNEs mainly takes place through tax havens, whereby European tax havens are far more important for German MNEs than tax havens outside Europe. Fourth, the larger they are (in terms of consolidated revenues), the more profits German MNEs shift to tax havens. Fifth, we demonstrate that using Orbis data in profit shifting regressions leads to biased estimates, as they contain a systematic measurement error.

This paper contributes to a growing body of research on tax avoidance by MNEs. The extent of tax avoidance by MNEs is typically assessed based on estimates of the tax-sensitivity of pre-tax profits. In a recent survey of the literature, Beer et al. (2020) review 37 studies that empirically evaluate the tax elasticity of MNE profits. These studies can be broadly divided into two groups. The first group uses micro data to assess the extent of tax avoidance and profit shifting at the firm level. The second group relies on macro data, that is, data aggregated at the country level. However, studies in both groups suffer from certain drawbacks.

Firm-level studies often rely on data from the Orbis or Amadeus database, provided by Bureau van Dijk and collected from public business registries. One problem with this data is that there is no information about the activities of MNEs in many countries, especially tax havens. A series of recent leaks as well as national accounts data suggest that MNEs book a significant share of their profits in tax havens (Zucman 2014; Tørsløv et al. 2018). Estimates of the total extent of profit shifting and tax avoidance by MNEs based on business registry data are thus likely to be biased downwards. To the best of our knowledge, micro evidence using data with complete coverage of MNEs' residence countries is restricted to US MNEs (Dowd et al., 2017). ${ }^{3}$

Macroeconometric analyses, on the other hand, have faced criticism for failing to control for MNEs' scale of real economic activity. This potentially results in biased estimates of the tax-sensitivity of corporate profits and an overstatement of the extent of profit shifting (Beer et al. 2020; Dharmapala 2014; Heckemeyer and Overesch 2017). Using financial accounting data

\footnotetext{
${ }^{3}$ Gumpert et al. (2016) focus on whether or not German MNEs have a tax haven presence, but do not estimate the amount of profit shifting.
} 
for US MNEs, Dyreng and Hanlon (2020) show that existing profit shifting estimates based on macro data tend to be implausibly large.

The CbC data we use avoids these problems. To the best of our knowledge, the only country that has made information from $\mathrm{CbC}$ reports publicly available so far is the US (GarciaBernardo et al., 2019). However, the US does not publish information at the MNE level. Instead, the information is aggregated across all US MNEs that are obliged to file a CbC report at the level of the countries where these MNEs have affiliates. Studies using this data thus suffer from similar problems to other macro approaches. Our data, in contrast, encompasses information from individual $\mathrm{CbC}$ reports, allowing us to assess the extent of profit shifting at the MNE level while controlling for real economic activity.

This new data allows us to contribute to the existing literature in several ways. First, the full coverage of large German MNEs' global activities enables us to provide a complete picture of the global distribution of their profits - including profits reported in tax havens - and to compare it to the global distribution of (tangible) assets, employment, and sales. Studies relying on Orbis or Amadeus data are not able to do so. Second, the completeness of the CbC data also allows us to provide a more credible estimate of the tax-sensitivity of corporate profits and the total amount of profits shifted to tax havens. Third, as the CbC reports contain information about revenues generated through transactions with other affiliates of the same MNE group, we are able to assess whether the location of subsidiaries that mainly provide inputs and services for associated firms is sensitive to the level of taxation. Intra-company trade, loans, and the strategic location of intellectual property (IP) are considered particularly important channels through which MNEs shift profits to low-tax jurisdictions (e.g., Buettner and Wamser 2013; Dischinger and Riedel 2011; Dyreng and Hanlon 2020; Fuest et al. 2011; Griffith et al. 2014). Because revenues from intra-firm transactions reported in the $\mathrm{CbC}$ reports include royalties and interest payments, it is possible to assess the relevance of these channels. Other financial data sources do not include this information.

The rest of the paper is organized as follows. Section 2 describes the CbC data and our sample of German MNEs. In Section 3, we investigate the global distribution of German MNEs' profits and factors of production. In addition, we analyze the profitability of German MNEs across tax havens and non-haven countries. Section 4 compares the $\mathrm{CbC}$ data to data from Bureau van Dijk's Orbis database. We introduce our regression model and show the results of our profit shifting regressions based on $\mathrm{CbC}$ data in Section 5. Section 6 presents estimates of the total amount of profits shifted to tax havens and the associated loss in corporate tax revenue. In Section 7, we re-estimate our regression model using Orbis data. Section 8 concludes. 


\section{CbC Data and Sample}

The data used for our analysis is taken from $\mathrm{CbC}$ reports filed by German MNEs. CbC reporting was initiated by the OECD and G20 in the context of the BEPS project. The CbC reports include information on the global activities of MNEs. They are prepared by the MNEs, and submitted to the tax authority of the country of the MNEs' headquarters. An MNE is legally obliged to submit a $\mathrm{CbC}$ report if its consolidated global group revenue exceeds a threshold of EUR 750 million (or an equivalent amount in a different currency), and if the country where its headquarters are based takes part in the OECD/G20 Inclusive Framework on BEPS, provided that the country has introduced a corresponding reporting obligation into national legislation. ${ }^{4}$ In general, membership in the Inclusive Framework on BEPS is open to all interested countries. However, membership requires commitment to certain minimum standards, the introduction of $\mathrm{CbC}$ reporting being one of them. As of December 2019, 137 countries joined the Inclusive Framework on BEPS, 90 of which already introduced a CbC reporting obligation into national legislation. ${ }^{5}$ In Germany, a CbC reporting obligation was introduced in 2016. The tax authority of the MNE's headquarters country shares the CbC report with the tax authorities of other Inclusive Framework members where subsidiaries of that MNE are located. However, the reports are not disclosed to the public. The goal of CbC reporting is to "[...] provide tax administrations with a high level overview of the operations and tax risk profile of the largest multinational enterprise groups" (OECD 2017, p. 11), allowing tax authorities to use their auditing capacities more efficiently. ${ }^{6}$

The $\mathrm{CbC}$ reports contain basic financial information about the global activities of an MNE. More precisely, they include the following information:

- Profit/loss before taxation

- Taxes paid

- Taxes accrued (year of reporting)

- Stated capital

- Accumulated earnings

- Number of employees (full-time equivalents)

- Net book value of tangible assets

- Revenues generated from transactions with independent parties (revenues unrelated), including revenues from sales of inventory and properties, services, royalties, interest, and premiums

\footnotetext{
${ }^{4}$ Note that a country may also require constituent entities of an MNE that are resident in that country for tax purposes to file a $\mathrm{CbC}$ report if the MNE is not obliged to do so in the country where it is headquartered and its consolidated group revenues exceed EUR 750 million ('local filing').

${ }^{5}$ A regularly updated list of Inclusive Framework member countries can be found here: https://www.oecd.org/tax/beps/beps-actions/action13/ (last accessed on 12 September 2020).

${ }^{6}$ Hugger (2020) provides more details on CbC reporting.
} 
- Revenues generated from transactions with associated enterprises (revenues related), including revenues from sales of inventory and properties, services, royalties, interest, and premiums

- Total revenues (revenues unrelated plus revenues related)

Note that the $\mathrm{CbC}$ reports do not contain information at the subsidiary level. Instead, the information is aggregated at the level of the tax jurisdictions where MNEs operate. Nevertheless, the information we use refers to activities of individual MNEs. Our analysis therefore uses a different level of aggregation than (most) existing micro- and macro-analyses. Micro-analyses typically use information at the subsidiary level and thus more disaggregated data than ours. Exceptions are the studies by Dowd et al. (2017) and Huizinga and Laeven (2008), who use data at the same level of aggregation. Macro-analyses (including those that use US CbC data, like Garcia-Bernardo et al. (2019)) typically use data aggregated by tax jurisdiction, which implies a higher level of aggregation.

Our data set covers the information from $\mathrm{CbC}$ reports filed by German MNEs for the years 2016 and 2017. The original data covers 386 German MNEs. However, we exclude some companies from our sample for different reasons. First, we exclude all non-corporate and public MNEs since they are subject to different tax regulations than corporate MNEs in Germany. Profits of incorporated enterprises are subject to the corporate income tax plus the local business tax, the latter being levied by the municipalities. Non-corporate enterprises have to pay the local business tax as well, but are not subject to the corporate income tax. Rather, their income is taxed at the level of the owner and, therefore, subject to the personal income tax. $^{7}$ Second, we exclude corporate groups that reported information for the financial years 2015 or 2018 in lieu of 2016 and/or 2017. Our final sample comprises 333 corporate MNEs. By definition, these companies all exceed the revenue threshold of EUR 750 million. Table A1 of the Appendix provides summary statistics for the CbC sample.

In a recent paper, Blouin and Robinson (2020) point out that certain types of income of MNEs may be double counted in financial accounting data. They identify three potential sources of double counting: (i) the income reported by a subsidiary may also be included in the financial statement of its parent company as equity income; (ii) the income reported by the parent company may include dividends received from its subsidiaries; (iii) the income of a conduit entity (such as a partnership) may be reported in both the conduit entity's financial statement and the financial statement of its owner(s). Using financial data from the Bureau of Economic Analysis (BEA) as an example, Blouin and Robinson (2020) demonstrate that failing to account for the double counting of certain income can lead to a severe overstatement of MNEs'

\footnotetext{
7 The corporate income tax rate in Germany is $15 \%$. The local business tax varies across municipalities, with an average of also $15 \%$, so that the overall statutory tax rate on corporate profits is, on average, equal to $30 \%$. The personal income tax is characterized by a progressive tax schedule, with an initial tax rate of $14 \%$ and a maximum tax rate of $45 \%$.
} 
profits, especially those reported in tax havens. The authors show that using unadjusted BEA data leads to estimates of the tax revenue loss for the US due to profit shifting in the range of $30 \%-45 \%$ of corporate tax revenues. Their correction for double counting reduce the estimated revenue losses to $4 \%-8 \%$, which is not far from our results for Germany, as will be explained further below.

The $\mathrm{CbC}$ reporting guidelines require MNEs to report their activities in a way that prevents a double counting of subsidiaries' income at the level of their parent company either as equity income or dividend income. Income stemming from partnerships, in contrast, might in fact be double counted (cf. Hanlon 2018). However, the $\mathrm{CbC}$ reporting guidelines provide that MNEs report the income from partnerships that is passed through to them in a separate row. We find that only six out of the 333 German MNEs in our sample report such income. It thus appears that this problem is only of minor relevance for our analysis. ${ }^{8}$

\section{Where do German MNEs report their profits?}

To gain an initial impression of the role tax havens play for the global activities of German MNEs, we compute two common profitability measures. These are the ratio of profits to tangible assets and the ratio of profits to the number of employees. We compare these measures across three country groups: (i) countries not considered tax havens (including Germany), (ii) European tax havens, and (iii) tax havens located outside of Europe. ${ }^{9}$ Note that there is disagreement in the literature concerning the countries which qualify as tax havens. Menkhoff and Miethe (2019) provide a summary of the classifications used in six different publications. For our analysis, we decided to include only those countries that are labeled accordingly in all of the six publications reviewed by Menkhoff and Miethe (2019) to our list of tax havens. We believe that this procedure yields the least arbitrary classification. ${ }^{10}$ The profitability measures are computed by dividing the sum of positive profits reported by all subsidiaries of German MNEs in each of these country groups by the value of tangible assets and the number of employees, respectively.

The results are illustrated in Figures 1 and 2. Subsidiaries located in European tax havens are far more profitable than subsidiaries located in non-havens. In European tax havens, the return to tangible assets is roughly $39 \%$, which is more than two times larger than the value for subsidiaries located in non-havens (Figure 2). Profits per employee reported in European tax havens are even three time larger than in non-havens (Figure 2). In tax havens outside of

\footnotetext{
${ }^{8}$ Note that eliminating those six MNEs from our sample has virtually no effect on the results of our analyses. Results are available upon request.

9 The numbers for non-havens also include the information of the parent companies located in Germany.

10 Table A2 in the Appendix provides the corresponding lists of European and non-European tax havens.
} 
Europe, the return to tangible assets is about $170 \%$ higher than in non-havens and profits per employee are $80 \%$ higher. These findings indicate that there is a notable imbalance between the global distribution of profits and the global distribution of factors of production.

Figure 1: Return to tangible assets

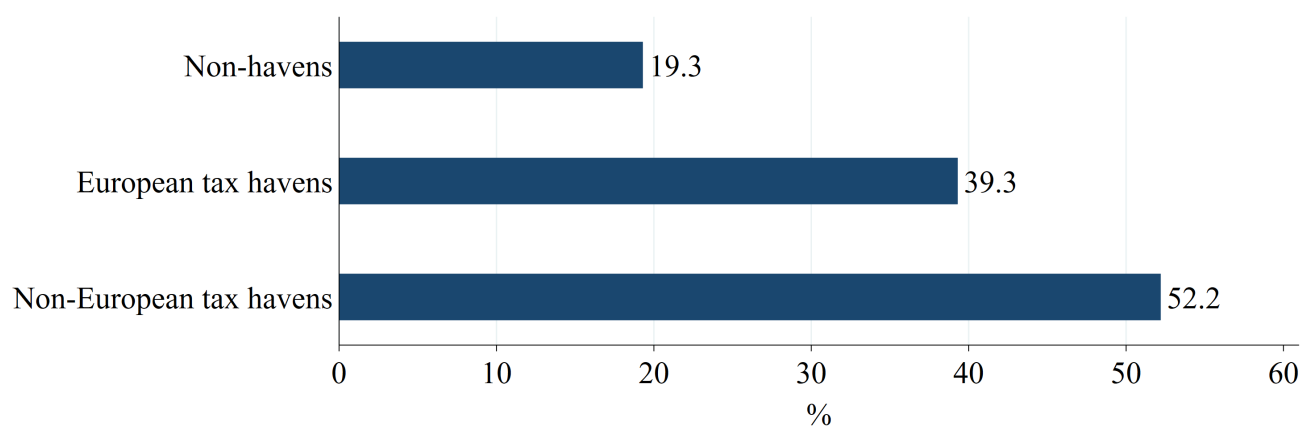

Notes: This figure shows the average ratio of pre-tax profits in revenues with unrelated parties for affiliates of large German MNEs in different country groups for the years 2016 and 2017.

Figure 2: Profits per employee

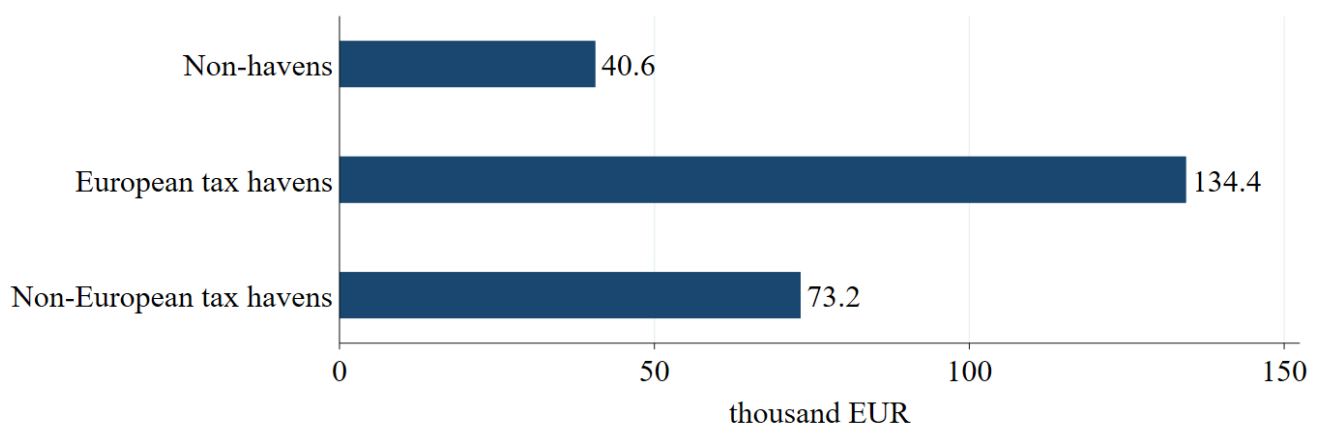

Notes: This figure shows the average ratio of pre-tax profits over the number of employees for affiliates of large German MNEs in different country groups for the years 2016 and 2017.

Figure 3 provides a first indication that differences in the taxation of corporate profits may play a role in explaining the cross-country differences in profitability. The figure shows effective average tax rates across the three country groups, calculated by dividing the sum of taxes paid by German MNEs in the respective country groups by the sum of profits. ${ }^{11}$ In 2016 and 2017, the effective average tax rate of German MNEs in non-haven countries was roughly $21 \%$. In both European and non-European tax havens, the effective average tax rate was only roughly half that size.

\footnotetext{
11 Note that we only use MNE-country observations with positive profits and tax payments when computing the effective average tax rates.
} 
Figure 3: Effective average tax rates (taxes over profits)

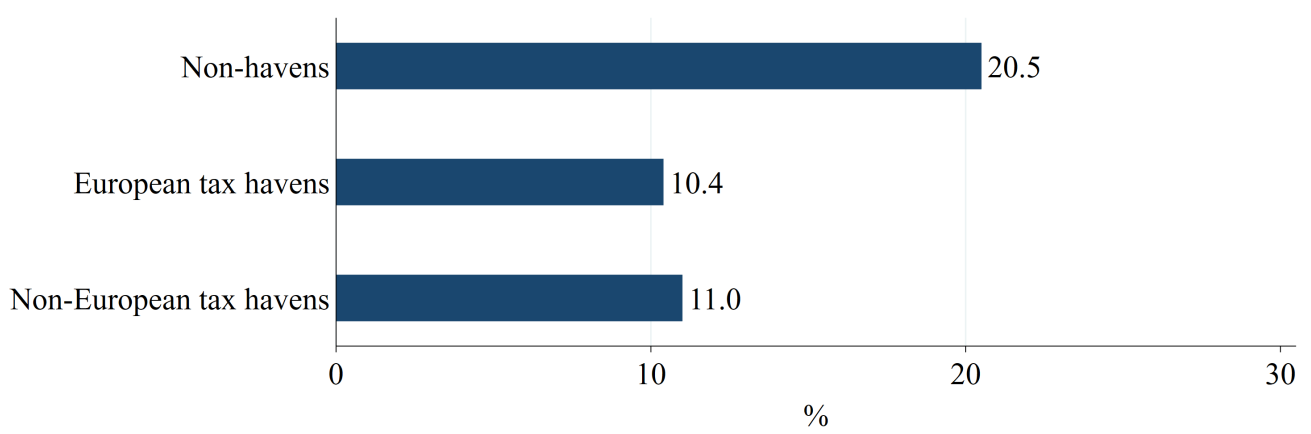

Notes: This figure shows the average ratio of taxes paid in pre-tax profits for affiliates of large German MNEs in different country groups for the years 2016 and 2017.

Figure 4: Intra-firm revenues over total revenues

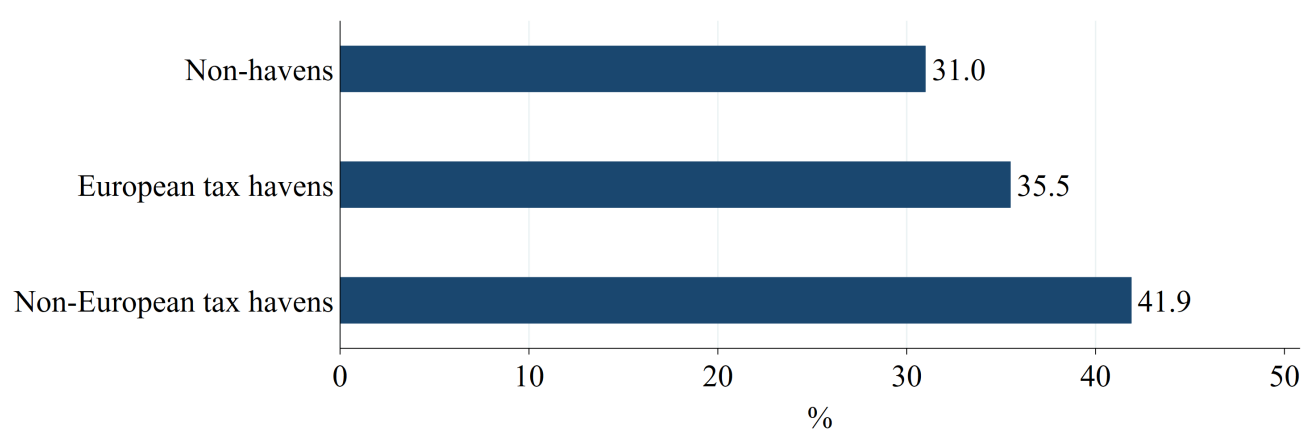

Notes: This figure shows the average share of intra-firm revenues in total revenues for affiliates of large German MNEs in different country groups for the years 2016 and 2017.

In a summary of the literature, Heckemeyer and Overesch (2017) identify three main channels through which MNEs may shift profits to low-tax jurisdictions. The first one is the transfer price channel. MNEs may locate subsidiaries that provide inputs for affiliate companies in lowtax jurisdictions, which then charge high transfer prices for these inputs. The second channel is the interest rate channel. Subsidiaries in low-tax jurisdictions may extend loans to affiliates located in high-tax jurisdictions and receive interest payments in return. Third, MNEs may strategically locate intangible assets such as patents, licenses, or trademarks in low-tax jurisdictions. Affiliates located in high-tax jurisdictions then pay fees or royalties for using these intangibles. The use of any one of these channels implies that subsidiaries located in low-tax jurisdictions generate revenues through intra-firm transactions. Figure 4 shows the share of intra-firm revenues in total revenues for the three country groups. The figure suggests that subsidiaries of German MNEs located in European and - even more so - non-European tax havens are particularly important for the provision of inputs and services for affiliated firms. Subsidiaries located in non-European tax havens (European tax havens) generate roughly $42 \%$ $(36 \%)$ of their revenues through transactions with affiliated firms. For subsidiaries in nonhavens, the share of intra-firm revenues is almost 11 percentage points (five percentage points) lower. Against the background of the higher profitability in tax havens, this finding may be 
interpreted as a first indication of a strategic location of inputs with the aim of shifting profits to low-tax jurisdictions.

The evidence presented thus far suggests that German MNEs in fact shift profits to reduce their tax burden. But how important are tax havens altogether? In other words, how large is the profit share German MNEs report in tax haven countries? Figure 5 provides the answer. In 2016 and 2017, just 9\% of German MNEs' global profits were booked in tax havens, while $91 \%$ were booked in non-havens. Considering that the political and public debate on profit shifting and tax avoidance by MNEs mainly focuses on the role of tax havens, this finding may come as a surprise. Another interesting insight provided by Figure 5 is that European tax havens appear to be far more important for German MNEs than tax havens outside of Europe. Approximately $87 \%$ of all tax-haven profits are booked in European tax havens, and only $13 \%$ in non-European tax havens.

As the profitability measures already indicated, the share of tangible assets and employees located in tax havens is disproportionately low compared to profits. Just $4 \%$ of German MNEs' assets and 3\% of employees (Figures A1 and A2 in the Appendix) are located in tax havens. Again, the shares for European tax havens are much larger than for non-European tax havens.

Figure 5: Global distribution of German MNEs' profits

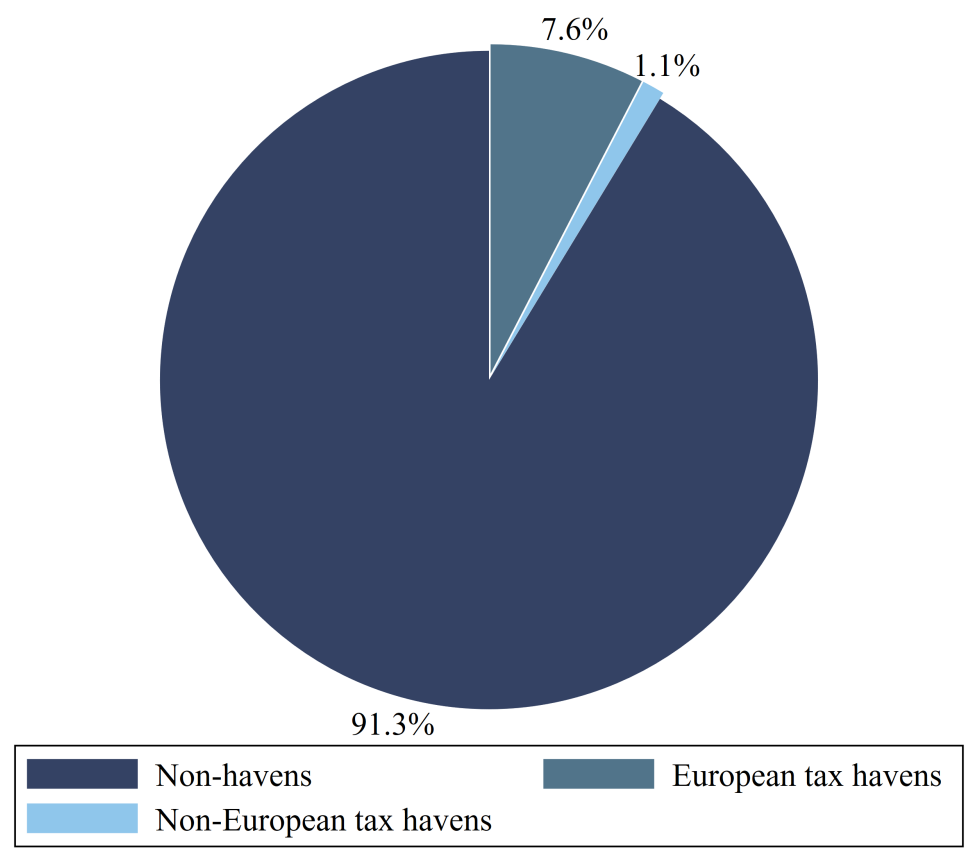

Notes: This figure shows the average distribution of large German MNE's pre-tax profits, assets, and employees across country groups for the years 2016 and 2017 . 


\section{Comparing $\mathrm{CbC}$ to Orbis data}

A large proportion of the existing literature on corporate tax avoidance and profit shifting, including studies by the OECD (Johansson et al., 2017), uses data from Bureau van Dijk's Orbis database for their analyses. It is thus worthwhile comparing it to the CbC data. Figure 6 compares the number of subsidiaries of German MNEs included in $\mathrm{CbC}$ and Orbis data as well as the information about the subsidiaries' global (unconsolidated) profits, tangible assets, and employment. ${ }^{12}$ Once again, we compare the information for three groups of countries: non-havens, European tax havens, and non-European tax havens. The numbers correspond to the ratio of the variables' realizations in the Orbis data to their realizations in the $\mathrm{CbC}$ data. Assuming that the information about German MNEs' global activities provided in the $\mathrm{CbC}$ data is complete (and we have no reason to doubt that), the numbers shed light on the coverage of the Orbis database.

Figure 6: Coverage of $\mathrm{CbC}$ data by Orbis

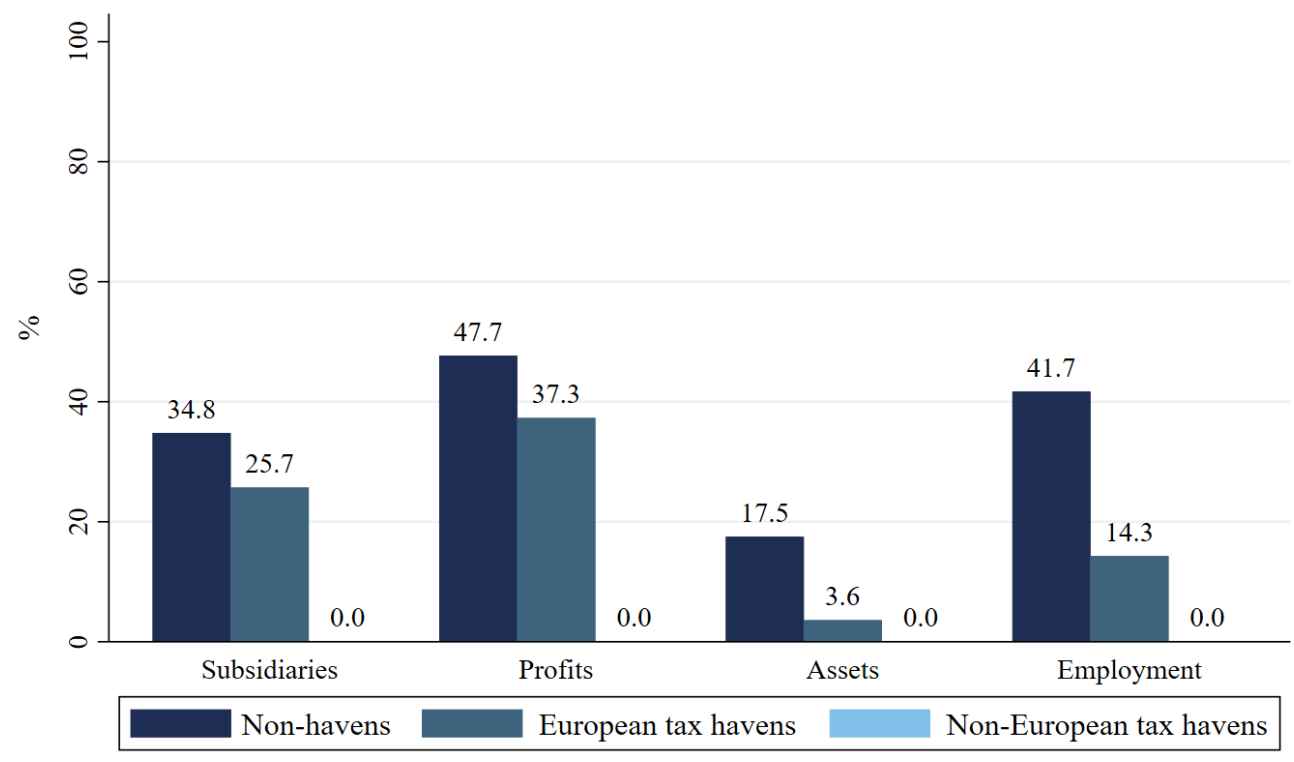

Notes: This figure compares the number of subsidiaries of German MNEs as well as subsidiaries' (unconsolidated) profits, tangible assets, and employment included in the $\mathrm{CbC}$ and Orbis data for different country groups. The figures represent the ratio of the variables' realizations in the Orbis data to their realizations in the $\mathrm{CbC}$ data.

Figure 6 indicates that the coverage of the Orbis data must be considered poor, especially in tax havens. Orbis only covers $35 \%$ of German MNEs' subsidiaries located in non-havens. The non-haven subsidiaries covered by Orbis account for approximately half (48\%) of the profits of all German MNEs' subsidiaries in these countries. The coverage of employment (42\%) and assets $(17 \%)$ in non-havens is even lower. In European tax havens, only $26 \%$ of the German

\footnotetext{
12 Summary statistics for the Orbis sample are provided in Table A3.
} 
MNEs' subsidiaries and $37 \%$ of the profits are accounted for in Orbis. Information about the activities in Cyprus, Liechtenstein, Malta, and Switzerland, which are all included in the list of European tax havens, are completely missing. What is more, Orbis does not cover any activities of the German MNEs included in our sample in tax havens outside of Europe.

The reasons for the incomplete coverage of the Orbis data are manifold. First, Orbis does not cover some countries since they do not keep business registries or do not publish the information therein. This is true for a large number of tax haven countries. Second, in some countries, the obligation to report financial information is limited to certain firm types. For example, it is quite common that reporting obligations only apply to large firms or firms of certain legal forms (cf. Kalemli-Ozcan et al. 2015. Third, some countries, despite being covered by Orbis as they keep public business registries, either do not require firms to report their profits, value of assets, and/or number of employees, or do not publish this particular information. Hence, the corresponding information is missing in Orbis. Fourth, the information about ownership structures and, hence, the list of subsidiaries in Orbis is incomplete.

Table A4 of the Appendix documents the coverage at the country level. According to the CbC reports, the 333 German MNEs included in our sample have subsidiaries in 193 countries. $79 \%(52 \%)$ have at least one subsidiary in a European (non-European) tax haven country. ${ }^{13}$ The Orbis data only covers subsidiaries in 46 of these countries. ${ }^{14}$ This means that Orbis lacks information for more than three quarters of the countries in which German MNEs have subsidiaries. What is more, in 21 of these 46 countries, less than half of the profits made by German MNEs are accounted for in Orbis. In contrast, the coverage of profits by Orbis is above $80 \%$ in only nine countries. Interestingly, there are four countries in our data set for which the ratio of profits reported in Orbis to profits reported in the $\mathrm{CbC}$ data exceeds $100 \%$. One potential explanation for this is the different treatment of profits made by legally dependent permanent establishments (PEs) between Orbis and $\mathrm{CbC}$ data. In Orbis, profits made by a legally dependent $\mathrm{PE}$ are reported at the level of its direct parent company. Hence, if the direct parent is located in country $\mathrm{A}$, but the PE is located in country $\mathrm{B}$, the profit of the PE is reported in $\mathrm{A}$. In the $\mathrm{CbC}$ data, on the other hand, the profit of a $\mathrm{PE}$ is reported in the country it is situated in, irrespective of the direct parent company's location. Note that the treatment of profits made by foreign PEs constitutes another important advantage of the CbC data over Orbis. When estimating the extent of tax avoidance and profit shifting, researchers

\footnotetext{
${ }^{13}$ Note that in our sample, the share of German MNEs with tax haven affiliates is notably larger than the share reported by Gumpert et al. (2016). Based on information from the German Bundesbank's Microdatabase Direct Investment (MiDi), the authors report that between 1996 and 2008, only about 20\% of German MNEs had tax haven affiliates. The authors also find that the likelihood that a German MNE has tax haven affiliates is positively related to firm size. Since our sample covers only the largest German MNEs, it seems likely that this positive relationship explains the different shares.

${ }^{14}$ Note that a large fraction of the 157 countries for which information is lacking are in fact covered in Orbis, but the realizations of the variables included in our empirical model are missing.
} 
are interested in where profits are actually booked, as opposed to where reporting takes place due to accounting conventions.

The incomplete coverage of the Orbis data is also documented by Tørsløv et al. (2018). The authors compare the consolidated global profits of MNEs to the sum of unconsolidated profits reported by those MNEs' subsidiaries that are covered by Orbis. They find that on average, it is only possible to trace $17 \%$ of MNEs' global profits in unconsolidated Orbis information.

\section{$5 \quad$ Profit shifting regressions based on $\mathrm{CbC}$ data}

\subsection{Empirical approach}

The imbalance between the global distribution of profits on the one hand and the distribution of fixed assets and employees on the other gives a first indication that German MNEs shift profits to low-tax jurisdictions (Section 3). Ultimately, though, the numbers presented above are only simple bivariate correlations. In this section, we use multivariate regressions to analyze the relationship between the global distribution of profits and corporate taxes in more detail.

We follow the empirical literature on corporate profit shifting and estimate a modified version of the empirical model proposed by Hines and Rice (1994). Our baseline specification is as follows:

$$
y_{i c t}=\alpha_{i}+\beta \tau_{c t}+\gamma^{\prime} \text { Firm }_{i c t}+\delta^{\prime} \text { Country }_{c t}+\theta_{t}+\epsilon_{i c t}
$$

Index $i$ refers to the corporate group, $c$ to the residence country of the group's affiliates, and $t$ to the year. ${ }^{15}$ We employ two different dependent variables in our analysis: (i) the log of the sum of profits before taxes of group $i$ 's affiliates located in country $c$ and (ii) the $\log$ of the sum of intra-firm revenues generated by group $i$ 's affiliates in country $c$. Note that the latter variable includes royalty and interest payments. An inverse relationship between this variable and the level of taxation in a country would thus provide (suggestive) evidence that the strategic location of inputs and services (including IP and financial services/intra-company loans) is an important instrument of profit shifting. ${ }^{16}$ The vector Firm includes three variables describing group $i$ 's activities in country $c$ and year $t$. These variables are the number of employees, the value of tangible assets, and the revenues group $i$ 's affiliates in country $c$ generated from sales to third parties (revenues unrelated). Arguably, the latter variable captures the importance of country $c$ as a market country for the group or as a hub through which MNEs serve consumers

\footnotetext{
15 In some cases, the financial year does not correspond to the calendar year. In those cases, we assign the financial information to year $t$ if the financial year ended before or on 30 June of the following year, and to year $t+1$ if the financial year ended after 30 June.

16 Admittedly, this variable is merely an imperfect indicator for the strategic location of IP and debt. Unfortunately, though, $\mathrm{CbC}$ reports do not contain separate information about royalty and interest payments.
} 
residing in other countries. ${ }^{17}$ The vector Country includes the log of PPP adjusted GDP per capita, log population (both taken from the Penn World Table 9.1; cf. Feenstra et al. 2015), as well as Amnesty International's Corruption Perception Index. $\alpha_{i}$ is a corporate group fixed effect, $\theta_{t}$ is a year fixed effect. Standard errors are clustered at the corporate group level. ${ }^{18}$

The variable of main interest is the tax variable $\tau$. In our empirical analysis, we use two different tax variables: (i) the statutory tax rate of country $c$ and (ii) the effective average tax rate. Existing studies either use the statutory tax rate (e.g., Huizinga and Laeven 2008; Dischinger and Riedel 2011) or effective average tax rates (e.g., Clausing 2016), but rarely both (an exception is Dowd et al. 2017). Statutory tax rates are taken from KPMG's Corporate Tax Surveys and EY's Annual Worldwide Corporate Tax Guides. Effective average tax rates are determined by dividing the sum of taxes MNEs in our sample pay in country $c$ by the sum of profits they report in this country. To circumvent endogeneity problems, we follow Dowd et al. (2017) and determine the effective average tax rate for group $i$ in country $c$ only based on the information about taxes paid and profits made by other MNEs in that country. Also, we compute effective average tax rates only for countries in which at least ten of the MNEs in our sample have affiliates. Due to that, our sample size is slightly smaller when using effective average tax rates instead of statutory tax rates. Note that since all MNEs in our sample have their headquarters in Germany, using the level of the tax rate in country $c$ as an explanatory variable is equivalent to using the difference between the tax rate in country $c$ and the tax rate in an MNE's base country.

To gain further insights, we modify our baseline specification in several ways. In a first modification, we follow Dowd et al. (2017) and add the squared realization of the tax variable to our baseline specification. This allows us to test whether the tax-sensitivity of profits and revenues varies across high and low-tax jurisdictions. The resulting regression equation is:

$$
y_{i c t}=\dot{\alpha}_{i}+\dot{\beta}_{1} \tau_{c t}+\dot{\beta}_{2} \tau_{c t}^{2}+\dot{\gamma}^{\prime} \text { Firm }_{i c t}+\dot{\delta}^{\prime} \text { Countr }_{c t}+\dot{\theta}_{t}+\dot{\epsilon}_{i c t}
$$

In a second modification, we add two dummy variables to our baseline specification. The first dummy variable takes on the value of 1 if country $c$ is a European tax haven, the second dummy takes on the value of 1 if country $c$ is a tax haven outside of Europe. The resulting regression equation is:

$$
y_{i c t}=\tilde{\alpha}_{i}+\tilde{\beta}_{1} \tau_{c t}+\tilde{\beta}_{2} \text { Haven }_{c}^{\text {European }}+\tilde{\beta}_{3} \text { Haven }_{c}^{\text {Non-European }}+\tilde{\gamma}^{\prime} \text { Firm }_{i c t}+\tilde{\delta}^{\prime} \text { Country } y_{c t}+\tilde{\theta}_{t}+\tilde{\epsilon}_{i c t}
$$

\footnotetext{
${ }^{17}$ Note that this variable also includes revenues affiliates located in country $c$ generate from sales to third-parties residing in other countries.

${ }^{18}$ Note that we do not include country fixed effects to our specification since there is virtually no variation in our tax variables and controls across the two sample years. However, even studies that cover longer time spans rarely control for country fixed effects.
} 
In a third modification, we test whether the tax-sensitivity of profits and intra-firm revenues varies across MNEs by re-estimating Equation (3) for different sub-samples. First, we create sub-samples based on information about the importance of intangible assets. To this end, we determine the ratio of the value of intangible assets to total assets and split our sample into four sub-samples based on the quartiles of that ratio. The information about the value of intangible assets comes from Orbis since it is not included in the CbC reports. ${ }^{19}$ Second, we test whether the tax-sensitivities vary depending on the size of the corporate group by creating four sub-samples based on the quartiles of total consolidated revenues.

Finally, we apply two additional modifications to test the robustness of our results. First, we replace the tax variable $\tau$ with the absolute difference between the tax rate in country $c$, and the weighted average of the tax rates of all other countries in which the corporate group has affiliates. Following Huizinga and Laeven (2008), we use the revenues generated by the corporate group's affiliates in a country as weights in the corresponding calculation. Second, we use a different approach to calculate effective average tax rates. We randomly draw a $10 \%$ (20\%) sample of MNEs and only use information about their profits and tax payments in different jurisdictions to calculate effective average tax rates. We repeat this procedure 10,000 times, each time estimating Equations (1) to (3) excluding the 10\% (20\%) of MNEs used to calculate the effective average tax rates. Then, we compute the average realizations of the coefficient estimates and their standard errors. However, the results of all specifications that we estimate remain robust to these two modifications. ${ }^{20}$

\subsection{Results}

\subsubsection{Baseline specification}

The results of our baseline specification are presented in Table 1. Columns (1) and (2) show the results when using profits as a dependent variable, Columns (3) and (4) when using intra-firm revenues.

Our results indicate a statistically significant association between the effective average tax rate on the one hand, and profits as well as intra-firm revenues on the other. Holding other factors such as the value of tangible assets, employment, and revenues fixed, a one percentage point (pp) increase in the effective average tax rate is associated with a decrease in profits by roughly $0.5 \%$ and a decrease in intra-firm revenues by $1.3 \%$. Thus, tax rate differentials between countries evidently play a role in the profit allocation of large German MNEs. However, despite their relevant magnitude, our estimates are notably smaller than the average semi-elasticities

${ }^{19}$ We use the consolidated information from Orbis, which is typically considered to be much more reliable than the unconsolidated information.

${ }^{20}$ We do not report the results here for reasons of space, but they are available from the authors upon request. 
reported in the meta-analyses by Beer et al. (2020) as well as Heckemeyer and Overesch (2017). Beer et al. (2020) find an average tax semi-elasticity of corporate profits of -1, Heckemeyer and Overesch (2017) of -0.8. The differences between those estimates and ours may be due to differences in the data used, or they may reflect the fact that German MNEs react less sensitively to tax rate differentials. This could be either because their asset structures or other characteristics make profit shifting more difficult, or because anti-tax avoidance legislation in Germany is more stringent than elsewhere.

Table 1: Results for the baseline specification

\begin{tabular}{lcccc}
\hline \hline Dependent Variable & \multicolumn{2}{c}{$\log$ (profits) } & \multicolumn{2}{c}{$\log$ (intra-firm revenues) } \\
\hline Statutory tax rate & $(1)$ & $(2)$ & $(3)$ & $(4)$ \\
Effective tax rate & 0.104 & & 0.380 & \\
& $(0.266)$ & & & \\
Log(Assets) & & $-0.517^{* *}$ & & $-1.262^{* * *}$ \\
& & $(0.183)$ & & $(0.318)$ \\
Log(Employment) & $0.153^{* * *}$ & $0.156^{* * *}$ & $0.262^{* * *}$ & $0.269^{* * *}$ \\
& $(0.040)$ & $(0.041)$ & $(0.069)$ & $(0.070)$ \\
Log(Revenues unrelated) & $0.369^{* * *}$ & $0.373^{* * *}$ & $0.930^{* * *}$ & $0.925^{* * *}$ \\
Corruption perception index & $(0.056)$ & $(0.058)$ & $(0.095)$ & $(0.097)$ \\
& $0.324^{* * *}$ & $0.315^{* * *}$ & $-0.128^{* * *}$ & $-0.133^{* * *}$ \\
Log(GDP pc) & $(0.030)$ & $(0.030)$ & $(0.038)$ & $(0.038)$ \\
Log(Population) & $\left(0.461^{* *}\right.$ & $0.384^{*}$ & $1.047^{* * *}$ & $0.935^{* * *}$ \\
Cummy year 2017 & $0.258^{* * *}$ & $0.279^{* * *}$ & $0.663^{* * *}$ & $0.644^{* * *}$ \\
Adjusted $R^{2 *}$ & $(0.050)$ & $(0.054)$ & $(0.094)$ & $(0.104)$ \\
\hline \hline Observations & $0.051^{* *}$ & $0.062^{* * *}$ & 0.058 & $0.081^{* *}$ \\
& $(0.019)$ & $(0.018)$ & $(0.033)$ & $(0.031)$ \\
& -0.058 & -0.064 & -0.036 & -0.036 \\
& $(0.052)$ & $(0.052)$ & $(0.086)$ & $(0.087)$ \\
& $1.910^{* * *}$ & $1.912^{* * *}$ & 0.698 & 0.990 \\
& $(0.514)$ & $(0.457)$ & $(0.890)$ & $(0.899)$ \\
\hline
\end{tabular}

Notes: Results are based on OLS regression. All specifications include corporate group fixed effects. Standard errors shown in parentheses are clustered at the corporate group level. ${ }^{*} /{ }^{* *} /{ }^{* * *}$ indicate significance at the $5 \% / 1 \% / 0.1 \%$ level.

In contrast, the relationships between statutory tax rates and profits as well as between statutory tax rates and intra-firm revenues are insignificant (Columns (1) and (3) of Table 1). One explanation for this finding is that the standard statutory tax rate is an inaccurate measure for the actual tax burden in a country. In fact, the coefficient of correlation between the effective average tax rate and the statutory tax rate in our data is only 0.24 , indicating a weak correlation between these two variables. Moreover, many countries consistently labeled 
as tax havens are in fact characterized by comparably high standard statutory tax rates. For example, Luxembourg has a statutory corporate income tax rate of $26 \%$, while Malta's is as high as $35 \%$. Discrepancies between effective average tax rates and statutory tax rates may be due to tax exemptions, tax credits for certain activities (such as R\&D), and/or patent boxes.

\subsubsection{Quadratic specification}

Dowd et al. (2017) argue that MNE affiliates located in low-tax jurisdictions may react more sensitively to tax rate differences than those in high-tax jurisdictions. This implies that the semi-elasticity of profits with respect to tax rates may be larger (in absolute terms) when the level of taxation in a country is low. To test this conjecture, Dowd et al. (2017) include the squared realization of the tax variable in their empirical model. We follow their approach and report the results for this modification in Table 2. To facilitate the interpretation of the coefficients, we also graphically illustrate the average marginal effects of a tax rate change for different tax rate levels. Figure 7 illustrates the marginal effects of a tax rate change on profits; Figure 8 shows the marginal effects of a tax rate change on intra-firm revenues.

Table 2: Results for the quadratic specification

\begin{tabular}{lcccc}
\hline \hline Dependent Variable & \multicolumn{2}{c}{$\log$ (profits) } & \multicolumn{2}{c}{$\log$ (intra-firm revenues) } \\
\hline & $(1)$ & $(2)$ & $(3)$ & $(4)$ \\
\hline Statutory tax rate & 1.410 & & 1.597 & \\
& $(0.914)$ & & $(1.613)$ & \\
Statutory tax rate squared & -2.311 & & -2.140 & \\
& $(1.499)$ & & $(2.614)$ & \\
Effective tax rate & & $-1.216^{*}$ & & $-2.872^{* * *}$ \\
& & $(0.515)$ & & $(0.806)$ \\
Effective tax rate squared & & 1.393 & & $3.306^{*}$ \\
& & $(0.942)$ & & $(1.465)$ \\
\hline Observations & 9410 & 9275 & 8338 & 8246 \\
F statistic (joint sign. tax variables) & 1.22 & $5.04^{* *}$ & 0.63 & $9.67^{* * *}$ \\
Adjusted $R^{2}$ & 0.797 & 0.798 & 0.718 & 0.721 \\
\hline \hline
\end{tabular}

Notes: Results are based on OLS regression. Coefficients of control variables are omitted to conserve space. All specifications include corporate group fixed effects. Standard errors shown in parentheses are clustered at the corporate group level. ${ }^{*} /{ }^{* *} /{ }^{* * *}$ indicate significance at the $5 \% / 1 \% / 0.1 \%$ level.

The results we obtain when using the effective average tax rate as an explanatory variable largely correspond with those reported by Dowd et al. (2017). The lower the level of taxation, the more sensitive profits are to tax rate differences. For instance, if the average tax rate is $10 \%$, a $1 \mathrm{pp}$ increase in the tax rate is associated with a decrease in profits by about $1 \%$ (cf. Figure 7). For an effective average tax rate of 25\%, the resulting marginal effect of a tax rate change is only half that size. Moreover, once the effective average tax rate exceeds 
a level of about 30\%, the marginal effect becomes insignificant. Note that the result of an F-test indicates that the coefficients of the linear and quadratic tax variable are jointly highly significant (second last row of Table 2). Thus, the weak individual significance of the coefficient estimates is apparently due to a collinear relationship. The results we obtain when using intrafirm revenues are qualitatively similar. Finally, we again do not find a statistically significant association (neither individually nor jointly) between statutory tax rates and profits or intrafirm revenues.

Figure 7: Marginal effect of tax rate change on profits

Panel A

Statutory tax rate change

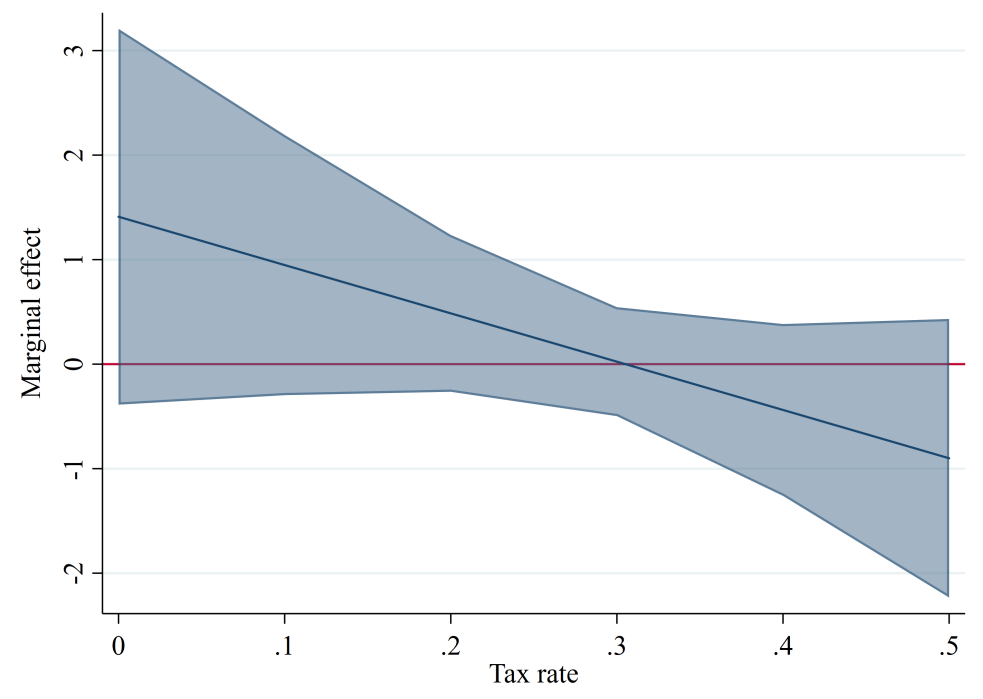

Panel B

Effective average tax rate change

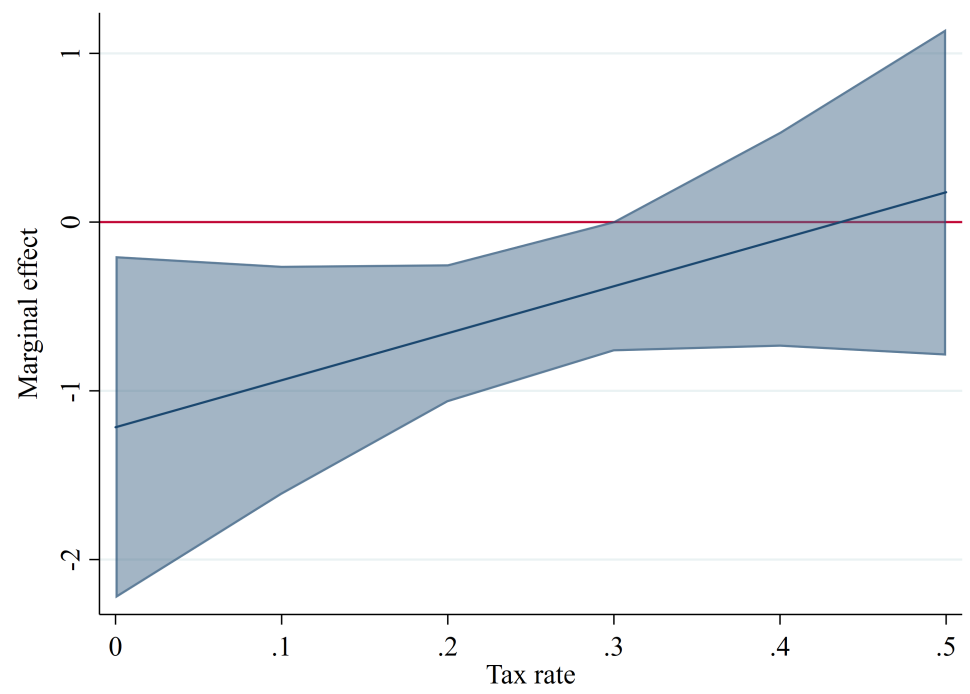

Notes: The figure illustrates the average marginal effects of a change in the statutory tax rate (Panel $\mathrm{A}$ ) and the effective average tax rate (Panel $\mathrm{B}$ ) on the log of profits for different realizations of the tax rate. Average marginal effects are computed based on the coefficient estimates in Table 2. The shaded areas show $95 \%$ confidence intervals. 
Figure 8: Marginal effect of tax rate change on intra-firm revenues

Panel A

Statutory tax rate change

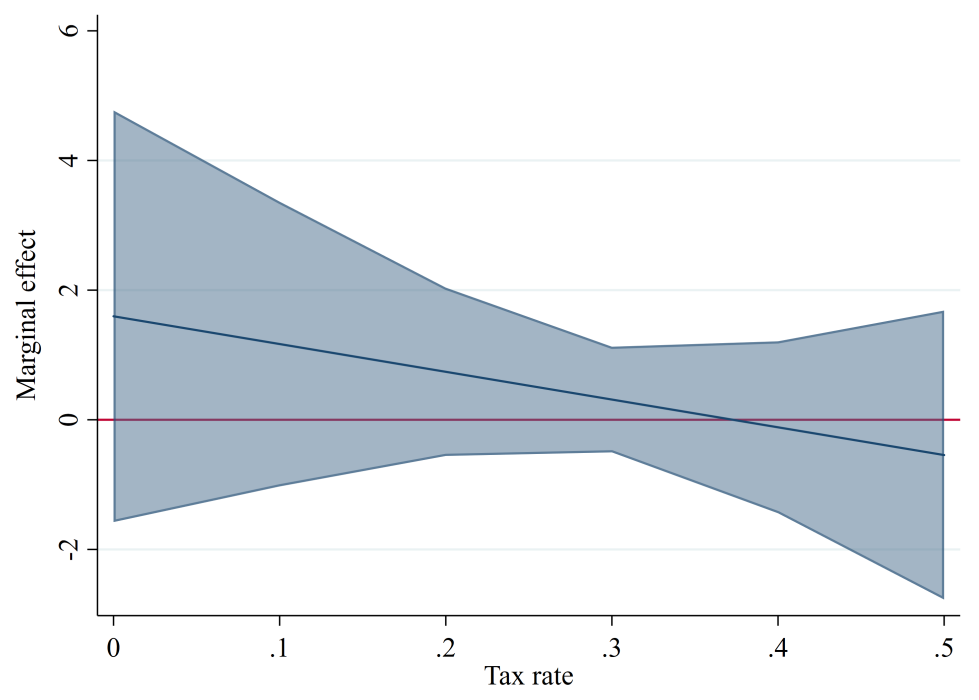

Panel B

Effective average tax rate change

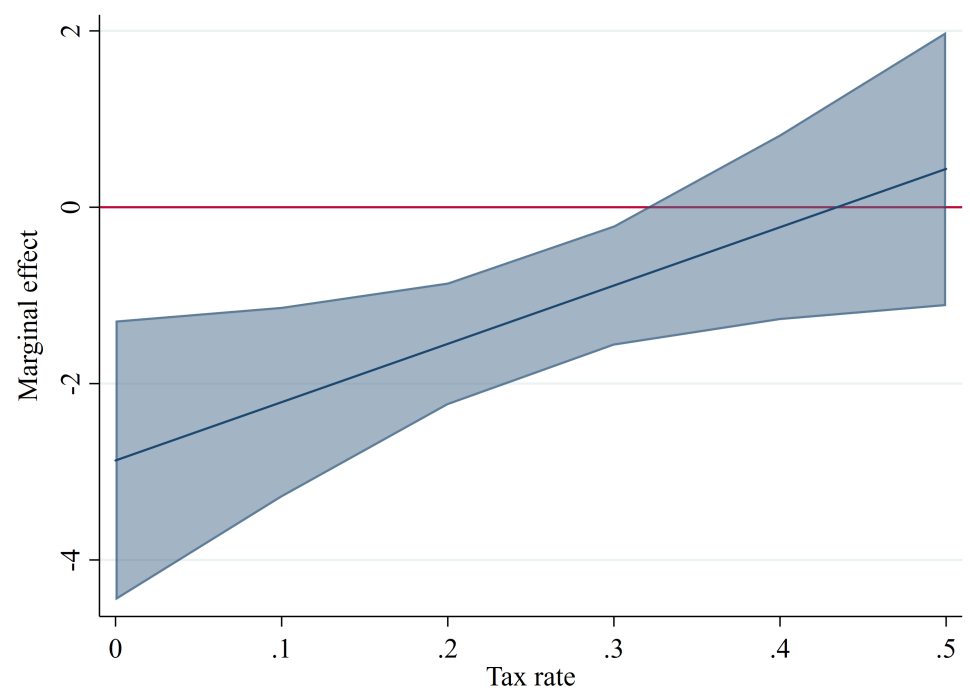

Notes: The figure illustrates the average marginal effects of a change in the statutory tax rate (Panel A) and the effective average tax rate (Panel B) on the log of intra-firm revenues for different realizations of the tax rate. Average marginal effects are computed based on the coefficient estimates in Table 2. The shaded areas show $95 \%$ confidence intervals.

\subsubsection{Including tax haven dummies}

In this section, we take a closer look at the importance of tax havens for German MNEs' profit shifting activities. Tax haven countries have been put under the spotlight due to scandals like the 'Luxemburg-Leaks' or the public exposure of tax avoidance strategies of well-known 
firms, including US companies like Apple or Amazon, but also German MNEs like Fresenius or BASF $^{21}$

Table 3 shows the regression results when including dummy variables for European and non-European tax havens in our baseline specification (Equation (3)). Our results are quite remarkable. When the two dummy variables are included, the estimate of the tax semi-elasticity of profits reduces by half in comparison with the baseline specification, and is no longer statistically significant. The coefficient estimates of the tax haven dummies, on the other hand, are not only statistically significant at every reasonable level of significance, but also sizable. Other factors fixed, the profits reported by large German MNEs in European tax havens exceed the profits reported in non-havens by more than $60 \%$. In non-European tax havens, profits are about $40 \%$ higher. These findings suggest that tax havens play a key role in the profit shifting activities of large German MNEs. European tax havens seem to be more important than non-European tax havens. In a similar vein, we find that for affiliates located in European (non-European) tax havens, intra-firm revenues are more than two-thirds (two times) higher than for affiliates located in non-havens. This finding suggests that large German MNEs strategically locate inputs in tax havens. The fact that intra-firm revenues are, ceteris paribus, higher in non-European tax havens than in European tax havens, despite German MNEs reporting higher profits in European tax havens, corresponds well with the stylized facts presented in Section 3. Note that the estimated tax semi-elasticity of revenues generated through intrafirm transactions remains statistically significant when the two dummy variables are included. However, its magnitude decreases (in absolute terms) as well.

Table 3: Including dummy variables for tax havens

\begin{tabular}{lcccc}
\hline \hline Dependent Variable & \multicolumn{2}{c}{$\log$ (profits) } & \multicolumn{2}{c}{$\log ($ intra-firm revenues) } \\
\hline Statutory tax rate & $(1)$ & $(2)$ & $(3)$ & $(4)$ \\
Effective tax rate & 0.532 & & $1.254^{* *}$ & \\
& $(0.274)$ & & $(0.453)$ & $-0.867^{* *}$ \\
European tax havens & & -0.249 & & $(0.325)$ \\
& & $(0.184)$ & & $0.690^{* * *}$ \\
Non-European tax havens & $0.665^{* * *}$ & $0.630^{* * *}$ & $0.774^{* * *}$ & $(0.124)$ \\
& $(0.080)$ & $(0.078)$ & $(0.126)$ & $1.004^{* * *}$ \\
\hline Observations & $(0.091)$ & $0.371^{* * *}$ & $1.104^{* * *}$ & $(0.151)$ \\
Adjusted $R^{2}$ & 9410 & $(0.091)$ & $(0.158)$ & 8246 \\
\hline \hline
\end{tabular}

Notes: Results are based on OLS regression. All specifications include corporate group fixed effects. Standard errors shown in parentheses are clustered at the corporate group level. ${ }^{* * *} / * * *$ indicate significance at the $5 \% / 1 \% / 0.1 \%$ level.

\footnotetext{
21 See for instance, Auerbach (2016).
} 


\subsubsection{Effect heterogeneity}

It is often argued that a high reliance on intangible assets facilitates profit shifting. In the BEPS project, for instance, the OECD highlights the importance of intangible assets for MNEs' tax avoidance activities (OECD, 2017). Also, Griffith et al. (2014) as well as Dischinger and Riedel (2011) provide evidence that the location of MNEs' intellectual property depends on the level of taxation. For that reason, we examine whether the estimated tax semi-elasticities of profits and intra-firm revenues vary with the share of intangible assets in total assets. To this end, we split our sample into four sub-samples based on the quartiles of this share and re-estimate Equation (3) for each sub-sample. Since the $\mathrm{CbC}$ reports do not contain information about intangible assets, we determine the ratio based on Orbis data and merge this information with the CbC data. ${ }^{22}$ The results are presented in Table 4. Overall, the findings do not indicate that the extent of profit shifting by German MNEs is related to the share of intangible assets. The coefficient estimates of the dummy variables for both European and non-European tax havens vary only slightly across the sub-samples. The only exception is the third quartile, where the coefficient estimate of the dummy for non-European tax havens is not statistically significant.

Another common claim is that larger firms are more likely to engage in profit shifting than smaller firms. The reason is that tax planning and profit shifting activities are associated with significant fixed costs, which large firms can bear more easily. These costs may include costs linked to staffing, legal advice, and to setting up companies abroad. Davies et al. (2018), Desai et al. (2006), Langenmayr and Liu (2020), as well as Wier and Reynolds (2018) provide evidence of a positive relationship between firm size and profit shifting activities. In addition, Gumpert et al. (2016) find that the likelihood for a German MNE to have tax haven affiliates increases with firm size. Taking up on this, we check whether the estimates of the tax semi-elasticity of profits vary with firm size. As a proxy for firm size, we use the consolidated revenues of the MNE groups. As was the case before, we split our sample into four sub-samples based on the quartiles of the firm size indicator, and re-estimate our empirical model for each sub-sample. Table 5 reports the results. The findings we obtain corroborate the view that large firms shift more profits. The profits reported in European tax havens by the smallest $25 \%$ of MNEs in our sample exceed the profits reported in non-havens by approximately $45 \%$. For the largest $25 \%$ of German MNEs in our sample, this effect grows to over $80 \%$. Moreover, we find that only the largest $50 \%$ of MNEs in our sample appear to use non-European tax havens to shift profits. For the smaller half, the coefficient estimate for the dummy for non-European tax havens is statistically insignificant. There is no clear pattern for intra-firm revenues, though.

\footnotetext{
${ }^{22}$ Note that information about the share of intangible assets is missing for 133 of the 333 MNEs included in our sample. The total number of observations therefore decreases to 9830 .
} 
Table 4: Semi-elasticities by intangible asset shares

\begin{tabular}{|c|c|c|c|c|c|c|c|c|}
\hline \multirow[t]{2}{*}{ Dependent Variable } & \multicolumn{8}{|c|}{$\log$ (profits) } \\
\hline & \multicolumn{2}{|c|}{ 1st quartile } & \multicolumn{2}{|c|}{ 2nd quartile } & \multicolumn{2}{|c|}{ 3rd quartile } & \multicolumn{2}{|c|}{ 4th quartile } \\
\hline \multirow[t]{2}{*}{ Statutory tax rate } & 0.477 & & 0.993 & & 1.174 & & -0.000 & \\
\hline & $(0.765)$ & & $(0.584)$ & & $(0.731)$ & & $(0.646)$ & \\
\hline \multirow[t]{2}{*}{ Effective tax rate } & & 0.527 & & -0.420 & & $-0.920^{*}$ & & -0.039 \\
\hline & & $(0.487)$ & & $(0.415)$ & & $(0.397)$ & & $(0.464)$ \\
\hline \multirow[t]{2}{*}{ European tax havens } & $0.722^{* *}$ & $0.730^{* * *}$ & $0.722^{* * *}$ & $0.661^{* *}$ & $0.725^{* * *}$ & $0.628^{* *}$ & $0.758^{* * *}$ & $0.722^{* * *}$ \\
\hline & $(0.217)$ & $(0.206)$ & $(0.204)$ & $(0.191)$ & $(0.186)$ & $(0.183)$ & $(0.185)$ & $(0.192)$ \\
\hline \multirow[t]{2}{*}{ Non-Eur. tax havens } & $0.469^{*}$ & $0.451^{*}$ & $0.696^{* *}$ & $0.579^{*}$ & 0.276 & 0.132 & $0.605^{* * *}$ & $0.657^{* * *}$ \\
\hline & $(0.210)$ & $(0.210)$ & $(0.213)$ & $(0.218)$ & $(0.217)$ & $(0.214)$ & $(0.161)$ & $(0.147)$ \\
\hline \multirow[t]{2}{*}{ Dependent Variable } & \multicolumn{8}{|c|}{ log(intra-firm revenues) } \\
\hline & \multicolumn{2}{|c|}{ 1st quartile } & \multicolumn{2}{|c|}{ 2nd quartile } & \multicolumn{2}{|c|}{ 3rd quartile } & \multicolumn{2}{|c|}{ 4th quartile } \\
\hline \multirow[t]{2}{*}{ Statutory tax rate } & -0.269 & & 2.222 & & 1.742 & & 1.780 & \\
\hline & $(0.972)$ & & $(1.316)$ & & $(1.235)$ & & $(0.941)$ & \\
\hline \multirow[t]{2}{*}{ Effective tax rate } & & -1.062 & & -0.453 & & -1.605 & & -0.731 \\
\hline & & $(0.949)$ & & $(0.960)$ & & $(0.868)$ & & $(0.437)$ \\
\hline \multirow[t]{2}{*}{ European tax havens } & 0.264 & 0.226 & $1.087^{* *}$ & $0.993^{*}$ & $1.108^{* * *}$ & $0.979^{* * *}$ & $1.210^{* * *}$ & $1.050^{* * *}$ \\
\hline & $(0.281)$ & $(0.276)$ & $(0.402)$ & $(0.392)$ & $(0.217)$ & $(0.222)$ & $(0.286)$ & $(0.273)$ \\
\hline \multirow[t]{2}{*}{ Non-Eur. tax havens } & $1.254^{* *}$ & $1.211^{* *}$ & $1.856^{* * *}$ & $1.683^{* * *}$ & $1.198^{*}$ & $1.010^{*}$ & $1.053^{* * *}$ & $0.923^{* * *}$ \\
\hline & $(0.418)$ & $(0.405)$ & $(0.465)$ & $(0.459)$ & $(0.448)$ & $(0.397)$ & $(0.232)$ & $(0.210)$ \\
\hline
\end{tabular}

Notes: Results are based on OLS regression. Coefficients of control variables are omitted to conserve space. All specifications include corporate group fixed effects. Standard errors shown in parentheses are clustered at the corporate group level. ${ }^{*} / * * / * *$ indicate significance at the $5 \% / 1 \% / 0.1 \%$ level.

Table 5: Semi-elasticities by firm size

\begin{tabular}{|c|c|c|c|c|c|c|c|c|}
\hline \multirow{3}{*}{$\begin{array}{l}\text { Dependent Variable } \\
\text { Statutory tax rate }\end{array}$} & \multicolumn{8}{|c|}{$\log$ (profits) } \\
\hline & \multicolumn{2}{|c|}{ 1st quartile } & \multicolumn{2}{|c|}{ 2nd quartile } & \multicolumn{2}{|c|}{ 3rd quartile } & \multicolumn{2}{|c|}{ 4th quartile } \\
\hline & $\begin{array}{l}-0.535 \\
(0.525)\end{array}$ & & $\begin{array}{c}0.849 \\
(0.480)\end{array}$ & & $\begin{array}{c}0.926 \\
(0.571)\end{array}$ & & $\begin{array}{c}0.950 \\
(0.494)\end{array}$ & \\
\hline Effective tax rate & & $\begin{array}{c}0.015 \\
(0.359)\end{array}$ & & $\begin{array}{l}-0.359 \\
(0.303)\end{array}$ & & $\begin{array}{l}-0.306 \\
(0.324)\end{array}$ & & $\begin{array}{l}-0.271 \\
(0.365)\end{array}$ \\
\hline European tax havens & $\begin{array}{c}0.433^{* *} \\
(0.139)\end{array}$ & $\begin{array}{c}0.452^{* *} \\
(0.137)\end{array}$ & $\begin{array}{c}0.584^{* * *} \\
(0.153)\end{array}$ & $\begin{array}{c}0.540^{* * *} \\
(0.147)\end{array}$ & $\begin{array}{c}0.780^{* * *} \\
(0.149)\end{array}$ & $\begin{array}{c}0.738^{* * *} \\
(0.148)\end{array}$ & $\begin{array}{c}0.872^{* * *} \\
(0.152)\end{array}$ & $\begin{array}{c}0.815^{* * *} \\
(0.162)\end{array}$ \\
\hline Non-Eur. tax havens & $\begin{array}{c}0.345 \\
(0.215)\end{array}$ & $\begin{array}{c}0.373 \\
(0.214) \\
\end{array}$ & $\begin{array}{c}0.228 \\
(0.210)\end{array}$ & $\begin{array}{c}0.141 \\
(0.212)\end{array}$ & $\begin{array}{c}0.662^{* * *} \\
(0.170)\end{array}$ & $\begin{array}{c}0.605^{* * *} \\
(0.175)\end{array}$ & $\begin{array}{c}0.476^{* *} \\
(0.139)\end{array}$ & $\begin{array}{l}0.418^{* *} \\
(0.133)\end{array}$ \\
\hline \multirow[t]{2}{*}{ Dependent Variable } & \multicolumn{8}{|c|}{$\log ($ intra-firm revenues $)$} \\
\hline & 1 st q & artile & 2nd $\mathrm{q}$ & artile & $3 \mathrm{rd} \mathrm{c}$ & artile & 4 th q & artile \\
\hline Statutory tax rate & $\begin{array}{l}1.765^{*} \\
(0.890)\end{array}$ & & $\begin{array}{c}1.699 \\
(1.024)\end{array}$ & & $\begin{array}{c}0.658 \\
(0.836)\end{array}$ & & $\begin{array}{c}1.198 \\
(0.651)\end{array}$ & \\
\hline Effective tax rate & & $\begin{array}{l}-0.666 \\
(0.795)\end{array}$ & & $\begin{array}{l}-1.413 \\
(0.797)\end{array}$ & & $\begin{array}{l}-0.101 \\
(0.453)\end{array}$ & & $\begin{array}{c}-1.072^{* *} \\
(0.371)\end{array}$ \\
\hline European tax havens & $\begin{array}{c}0.192 \\
(0.242)\end{array}$ & $\begin{array}{c}0.074 \\
(0.240)\end{array}$ & $\begin{array}{c}0.807^{* *} \\
(0.295)\end{array}$ & $\begin{array}{c}0.725^{*} \\
(0.283)\end{array}$ & $\begin{array}{c}1.060^{* * *} \\
(0.206)\end{array}$ & $\begin{array}{c}1.025^{* * *} \\
(0.204)\end{array}$ & $\begin{array}{c}1.155^{* * *} \\
(0.189)\end{array}$ & $\begin{array}{c}1.050^{* * *} \\
(0.180)\end{array}$ \\
\hline Non-Eur. tax havens & $\begin{array}{l}0.898^{* *} \\
(0.280)\end{array}$ & $\begin{array}{c}0.704^{* *} \\
(0.256)\end{array}$ & $\begin{array}{c}1.277^{* * *} \\
(0.349)\end{array}$ & $\begin{array}{c}1.139^{* * *} \\
(0.325)\end{array}$ & $\begin{array}{c}1.287^{* * *} \\
(0.300)\end{array}$ & $\begin{array}{c}1.232^{* * *} \\
(0.296)\end{array}$ & $\begin{array}{c}0.962^{* * *} \\
(0.254)\end{array}$ & $\begin{array}{l}0.907^{* *} \\
(0.259)\end{array}$ \\
\hline
\end{tabular}

Notes: Results are based on OLS regression. Coefficients of control variables are omitted to conserve space. All specifications include corporate group fixed effects. Standard errors shown in parentheses are clustered at the corporate group level. ${ }^{*} / * * / * *$ indicate significance at the $5 \% / 1 \% / 0.1 \%$ level. 


\section{Calculating the amount of shifted profits}

Based on the results of the specification including tax haven dummies (cf. Column (1) of Table 3 ), we derive a rough estimate of the total amount of profits shifted to tax havens by large German MNEs. Our estimates suggest that in 2016 and 2017 combined, large German MNEs shifted approximately EUR 18.3 billion to tax havens. This equals almost $40 \%$ of the total profits the MNEs in our sample reported in tax havens, which was EUR 47.3 billion (first column of Table 6).

To estimate how much profit was shifted out of Germany vis-à-vis other non-haven countries, we re-allocate the shifted profits to Germany and other non-haven countries based on the distribution of tangible assets. Our estimates suggest that in 2016 and 2017, EUR 10.7 billion of profits were shifted out of Germany, corresponding to $4.3 \%$ of profits actually reported in Germany (second and third column of Table 6). The amount of profits shifted out of other non-haven countries was somewhat smaller; it was equal to EUR 7.6 billion or $3 \%$ of the profits reported in those countries. Note that these numbers are combined for the years 2016 and 2017. Translated into yearly averages, large domestic MNEs shift EUR 5.4 billion in profits out of Germany each year. Multiplied with a statutory tax rate of $30 \%$, this implies annual revenue losses for Germany amounting to EUR 1.6 billion.

Table 6: Profit shifting by large German MNEs in 2016 and 2017 combined

\begin{tabular}{lccc}
\hline \hline & $\begin{array}{c}\text { Reported profits } \\
\text { (bn. EUR) }\end{array}$ & $\begin{array}{c}\text { Shifted profits } \\
\text { (bn. EUR) }\end{array}$ & $\begin{array}{c}\text { Shifted profits / } \\
\text { Reported profits }\end{array}$ \\
\hline Germany & 247.6 & -10.7 & $-4.3 \%$ \\
Other non-havens & 250.4 & -7.6 & $-3.0 \%$ \\
European tax havens & 41.4 & +16.6 & $+40.1 \%$ \\
Non-European tax havens & 5.9 & +1.7 & $+28.8 \%$ \\
\hline Sum & 545.3 & 0 & - \\
\hline \hline
\end{tabular}

We should bear in mind that the estimates presented in Table 6 exclude profits shifted by German subsidiaries of foreign MNEs, and by domestic MNEs with revenues below EUR 750 million. In order to obtain a rough estimate of the total amount of profits shifted to tax havens out of Germany, we make some simple extrapolations.

In 2016 and 2017 combined, the total amount of corporate profits reported in Germany was approximately EUR 1,044.4 billion. ${ }^{23}$ This figure includes the profits reported by domestic

${ }^{23}$ Source: German Federal Statistical Office, Sector Accounts. 
MNEs, domestic non-MNEs, and German subsidiaries of foreign MNEs. Unfortunately, we do not know the contribution of each firm type to the EUR 1,044.4 billion of total profits. However, what we do know is the aggregate gross operating surplus for each of the three firm types. If we assume that each firm type's contribution to the EUR 1,044.4 billion of total profits corresponds to the relative contributions to gross operating surplus, we obtain an estimate of the annual profits of domestic MNEs (including those MNEs covered by the $\mathrm{CbC}$ data and those that are not covered) of EUR 654.5 billion, and for German subsidiaries of foreign MNEs of EUR 233.9 billion EUR (Table 7). ${ }^{24}$ If domestic MNEs with revenues below the EUR 750 million threshold shifted just as much of their profits to tax havens as MNEs covered by the CbC data, another EUR 17.4 billion would be added to our estimate of EUR 10.7 billion, yielding EUR 28.1 billion. This probably overestimates profits shifted by these firms because smaller companies tend to engage less in profit shifting than larger ones (cf. Section 5.2.4). Furthermore, if we assume that foreign MNEs' German subsidiaries shift the same share of their profits out of Germany and to tax havens as large German MNEs with their domestic activities (4.3\%), profits shifted by foreign MNEs during the two years considered here would amount to another EUR 10.1 billion. This leads to an estimate of overall corporate profits shifted out of Germany of EUR 38.2 billion for 2016 and 2017 combined or EUR 19.1 billion on average per year. Multiplied with the statutory tax rate of $30 \%$, this implies an annual tax revenue loss of EUR 5.7 billion.

Table 7: Profit shifting out of Germany in 2016 and 2017 combined

\begin{tabular}{lccc}
\hline \hline & $\begin{array}{c}\text { Profits reported in } \\
\text { Germany (bn. EUR) }\end{array}$ & $\begin{array}{c}\text { Shifted profits } \\
\text { (bn. EUR) }\end{array}$ & $\begin{array}{c}\text { Impact on tax } \\
\text { revenue }\end{array}$ \\
\hline Large German MNEs & 247.6 & -10.7 & -3.2 \\
Smaller German MNEs & 406.9 & -17.4 & -5.2 \\
Foreign MNEs in Germany & 233.9 & -10.1 & -3.0 \\
German non-MNEs & 156.0 & - & -11.4 \\
\hline Sum & 1044.4 & -38.2 & - \\
\hline \hline
\end{tabular}

In a recent paper, Tørsløv et al. (2018) estimate the amount of corporate profit shifting by combining national accounts data with information from the OECD's foreign affiliates statistics and balance of payments data. They do so on a global scale as well as for individual countries. The data they use are for the year 2015. For Germany, Tørsløv et al. (2018) estimate that the amount of profits shifted out of the country to tax havens equals USD 55 billion (EUR 50 billion), which is notably higher than our estimate of EUR 19.1 billion per year.

Another important finding in Tørsløv et al. (2018) is that if all firms had to pay the same

24 The remaining EUR 156.0 billion in corporate profits come from German non-MNEs. 
effective corporate tax rate in all countries, profit shifting would disappear and profits reported in tax havens would fall by $60 \%$. If we divide our estimate of EUR 18.3 billion of profits that large German MNEs shifted to tax havens by the EUR 47.3 billion of total profits they report in tax havens, we obtain approximately $40 \%$, which is notably smaller, too.

It is important to interpret profit shifting estimates with respect to the counterfactuals implied by the estimation methods used. These counterfactuals tell us how profits would be distributed globally in the absence of profit shifting. ${ }^{25}$ In our estimates documented in Table 7 , the counterfactual is a world where the global distribution of profits is determined by the control variables in our regressions; these include firm-level indicators of 'real' economic activity - employment, tangible assets, sales to third parties - and host country variables like GDP and population.

To illustrate the importance of the assumed counterfactual, consider a similar, but simpler approach: a world where profits are distributed in the same way as factors of production, that is, employment and tangible assets. If the counterfactual distribution of the large German MNEs' profits covered by the $\mathrm{CbC}$ data corresponded to the distribution of employment and tangible assets (with equal weights on both indicators), we would find that profit shifting out of Germany to tax havens would be roughly EUR 10 billion per year. That is almost twice as much as the estimate reported in Table 7. Profit shifting of German MNEs' foreign subsidiaries out of other non-haven countries would equal EUR 3.4 billion, which is close to our estimate (Table 6). In Tørsløv et al. (2018), the counterfactual is that the profit-to-payroll ratio of foreign MNEs' tax haven subsidiaries is the same as that of local firms. This assumption is not without problems because MNEs are generally more profitable than smaller firms operating only locally. Assuming that all tax haven profits exceeding a threshold that is determined based on the profitability of local firms are shifted may thus lead to an overstatement of shifted profits.

\section{Profit shifting regressions based on Orbis data}

To check whether using (incomplete) Orbis data yields different results for the tax semi-elasticity of corporate profits than the $\mathrm{CbC}$ data, we re-estimate the linear specification, the quadratic specification, and the specification including tax haven dummies based on Orbis data. To this end, we collect information on unconsolidated profits, taxes paid, tangible assets, employment, and revenues of the entities of German MNEs covered in the CbC data from the Orbis

\footnotetext{
${ }^{25}$ See Dyreng and Hanlon (2020) for a more thorough discussion of the relevance of counterfactuals for the estimation of profit shifting.
} 
database. ${ }^{26}$ We then aggregate this information at the level of the subsidiaries' residence countries for each MNE so that the data are at the same level of aggregation as the CbC data. ${ }^{27}$ Thus, our empirical approach is the same as the one outlined in Section 5.1. Table 8 shows the results.

Table 8: Results based on Orbis data

\begin{tabular}{|c|c|c|c|c|c|c|}
\hline \multirow[t]{2}{*}{ Dependent Variable } & \multicolumn{6}{|c|}{$\log$ (profits) } \\
\hline & (1) & $(2)$ & $(3)$ & $(4)$ & $(5)$ & (6) \\
\hline Statutory tax rate & $\begin{array}{l}-1.165 \\
(0.600)\end{array}$ & $\begin{array}{l}-1.692 \\
(2.402)\end{array}$ & & & $\begin{array}{l}-0.667 \\
(0.610)\end{array}$ & \\
\hline Statutory tax rate squared & & $\begin{array}{c}1.124 \\
(4.993)\end{array}$ & & & & \\
\hline Effective tax rate & & & $\begin{array}{c}0.034 \\
(0.467)\end{array}$ & $\begin{array}{c}-10.623^{* * *} \\
(2.164)\end{array}$ & & $\begin{array}{l}1.419^{* *} \\
(0.459)\end{array}$ \\
\hline Effective tax rate squared & & & & $\begin{array}{c}25.690^{* * *} \\
(4.876)\end{array}$ & & \\
\hline European tax havens & & & & & $\begin{array}{c}0.772^{* * *} \\
(0.163)\end{array}$ & $\begin{array}{c}1.069^{* * *} \\
(0.162)\end{array}$ \\
\hline Non-European tax havens & & & & & $\overline{(-)}$ & $\begin{array}{l}- \\
(-)\end{array}$ \\
\hline Observations & 3349 & 3349 & 3316 & 3316 & 3349 & 3316 \\
\hline F statistic (joint sign. tax variables) & - & 1.93 & - & $14.59^{* * *}$ & - & - \\
\hline Adjusted $R^{2}$ & 0.791 & 0.791 & 0.791 & 0.795 & 0.794 & 0.796 \\
\hline
\end{tabular}

What is striking is that we lose almost two-thirds of our observations when using Orbis data. The reason is a drastic reduction in the number of countries included in the sample. While the CbC data document activities of German MNEs in 193 countries, our Orbis sample covers only 46 countries (see Section 4 ).

The estimates we obtain based on Orbis data present a very different picture compared to the results based on $\mathrm{CbC}$ data. The linear specification yields an estimate of notable size for the coefficient of the statutory tax rate, and with a p-value just above the $5 \%$ level of significance $(\mathrm{p}=0.053)$. According to this estimate, a one pp increase in the statutory tax rate is associated with a $1.2 \%$ decrease in profits. However, the quadratic specification yields coefficient estimates for the statutory tax rate that are statistically insignificant both individually

\footnotetext{
${ }^{26}$ Note that Orbis data do not contain information about intra-firm revenues, which is why we use the log of total revenues as a control variable instead. However, the estimates we obtain based on $\mathrm{CbC}$ data remain unaffected when replacing the revenues generated through sales to third parties by total revenues.

${ }^{27}$ Note that Huizinga and Laeven (2008) use the same approach to estimate the extent of profit shifting by MNEs.
} 
and jointly. For the effective average tax rate, we obtain an insignificant coefficient estimate in the linear specification, but individually and jointly significant estimates in the quadratic specification. The resulting marginal effects demonstrate an odd pattern, though (cf. Figure 9). For low-tax jurisdictions, we observe an unreasonably large reaction to an increase in the effective average tax rate. In countries with an effective average tax rate of $10 \%$ (which roughly corresponds to the 10th percentile), a one pp hike in the tax rate is associated with a reduction in profits by about $5 \%$. Once the effective average tax rate exceeds a level of roughly $20 \%$ (which is close to the sample median), the tax semi-elasticity becomes significantly positive. Only the coefficient estimate of the dummy variable for European tax havens remains relatively stable. $^{28}$

But why is it that in the baseline specification, the coefficient estimate of the statutory tax rate proves to be (almost) statistically significant and of notable size when using Orbis data, while it is insignificant and close to zero when using $\mathrm{CbC}$ data? It is likely that this is related to the poor coverage of the Orbis data. In Section 4, we discussed different reasons for the poor coverage, including (i) an incomplete coverage of countries, (ii) an incomplete list of subsidiaries, and (iii) missing values in the variables of interest. The first reason implies that the results based on Orbis data may be subject to a sample selection bias. The other two reasons imply that the dependent (and some of the independent) variables included in our empirical model are measured with an error when using Orbis data, which may lead to biased estimates as well.

To check the relevance of these two explanations, we perform two tests. First, we reestimate our baseline specification using the $\mathrm{CbC}$ data, but only include those 46 countries in our sample that are also covered in the Orbis data. If the differences in results are due to a sample selection bias, then restricting our $\mathrm{CbC}$ sample to these countries should produce similar coefficient estimates to those Table 9 . However, when doing so, we obtain a coefficient estimate for the statutory tax rate that is statistically insignificant at every reasonable level of significance. In contrast, the coefficient estimate of the effective average tax rate grows to -1.3 (in absolute terms) and is significant even at the $0.1 \%$ level. These findings indicate that the omission of countries not covered by the Orbis data is not sufficient for explaining the different results based on the two data sets.

In the second test, we try to assess whether the measurement error in the dependent variable, that is, the sum of profits made by an MNE in a country, may explain the different results. The existence of a measurement error implies that the error term of Equation (1) comprises

${ }^{28}$ We do not obtain a coefficient estimate for the dummy for non-European tax havens since the countries labeled as such are not covered by the Orbis data. 
two components when using Orbis data:

$$
\epsilon_{i c t}=\vartheta_{i c t}+e_{i c t}
$$

where $\epsilon_{i c t}$ is the measurement error and $\vartheta_{i c t}$ is the idiosyncratic component of the composite error term. Under the standard assumption that $E(e \mid X)=E(e)=0$, OLS will yield unbiased coefficient estimates. In our application, though, this assumption is violated for two reasons. First, apart from a few exceptions (see Section 4), the measurement error is strictly negative as Orbis underreports aggregate MNE profits in the host countries. This violation implies that $E(e) \neq 0$; however, it does not necessarily lead to biased coefficient estimates for the explanatory variables. ${ }^{29}$ Second, we find that coverage of the Orbis data is inversely related to the statutory tax rate, implying that $E(e \mid X) \neq E(e)$. The coefficient of correlation between the statutory tax rate on the one hand, and the ratio of profits reported in Orbis to profits reported in the $\mathrm{CbC}$ data on the other hand, is -0.54 , which is considerable. The negative relationship implies that the extent of underreporting tends to be larger in countries with high statutory tax rates, which, in turn, leads to a downward bias in the OLS estimate of the statutory tax rate's (negative) coefficient. Given the large size of the correlation coefficient, it is not surprising that the bias is so severe. Our findings thus clearly indicate that it is necessary to exercise great caution when interpreting the results of profit shifting regressions based on unconsolidated Orbis data.

One reason for the fact that the extent of underreporting of profits in Orbis tends to be larger in high-tax countries could be the different treatment of profits by PEs in the two data sets. In the $\mathrm{CbC}$ data, profits of PEs are reported in the country where the PE is situated, while in Orbis, they are reported in the residence country of its direct parent company (cf. Section 4). Consequently, if German MNEs largely rely on legally dependent PEs to run their operations in high-tax jurisdictions, while their legally independent subsidiaries are situated in low-tax jurisdictions, the ratio of profits reported in Orbis to the profits reported in CbC would indeed be inversely related to the statutory tax rate.

\footnotetext{
${ }^{29}$ Using Monte Carlo simulations, Millimet and Parmeter (2019) show that strictly negative or positive measurement errors (which the authors refers to as 'one-sided measurement errors') mainly affect the estimate of the intercept, but not the estimates of the control variables' coefficients, provided that the measurement error is not correlated with the explanatory variables.
} 
Figure 9: Marginal effect of tax rate change on profits - Orbis data

Panel A

Statutory tax rate change

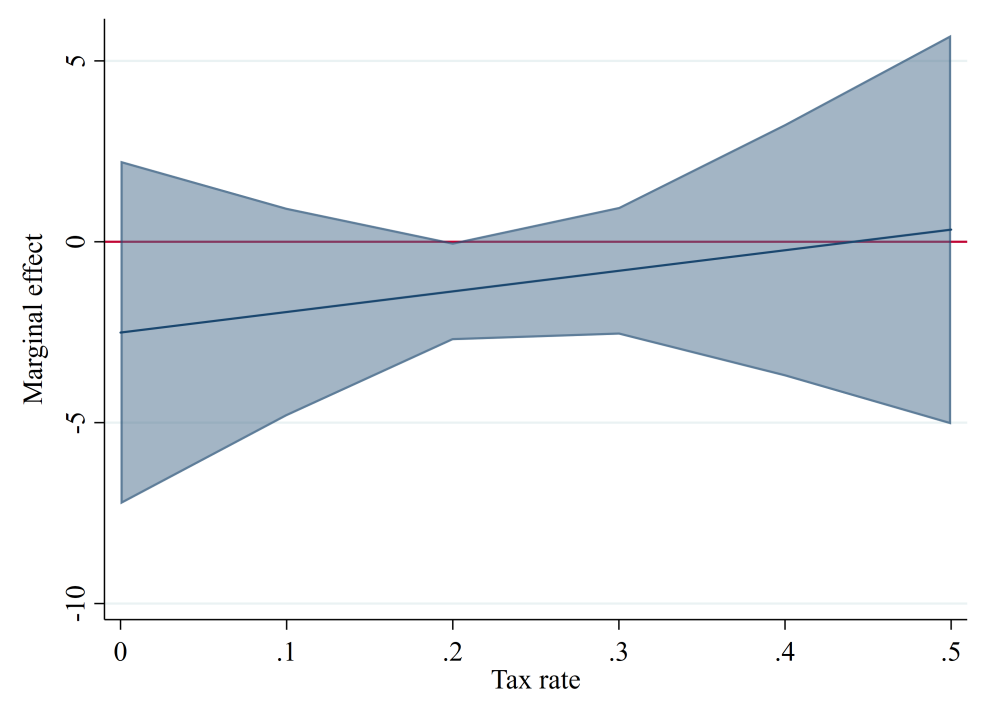

Panel B

Effective average tax rate change

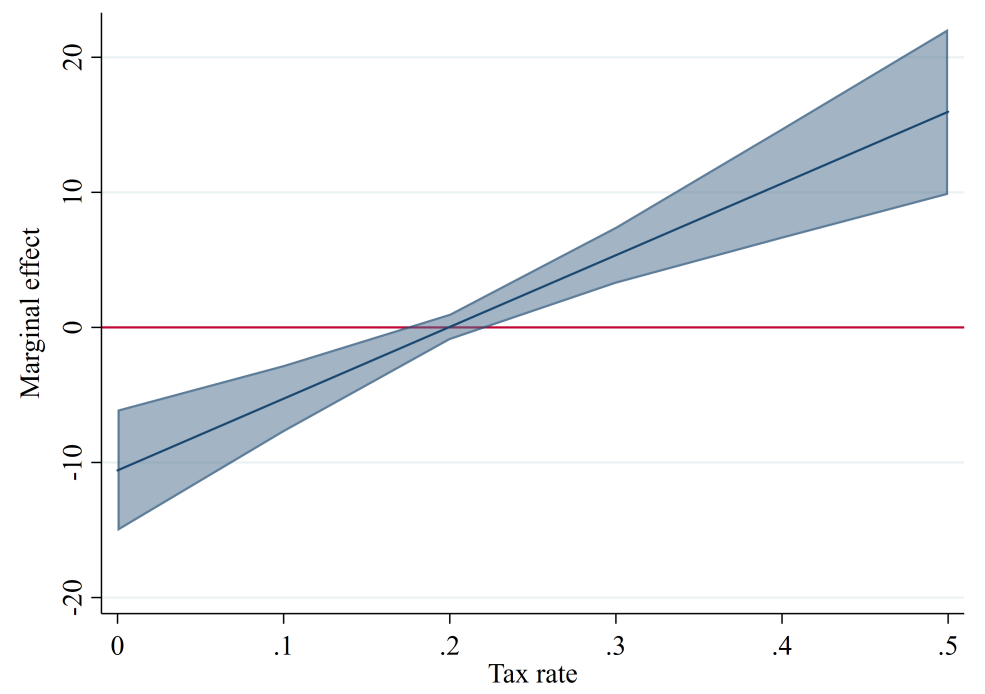

Notes: The figure illustrates the average marginal effects of a change in the statutory tax rate (Panel A) and the effective average tax rate (Panel B) on the log of profits for different realizations of the tax rate. Average marginal effects are computed based on the coefficient estimates in Table 8 . The shaded areas show 95\% confidence intervals. 


\section{Conclusions}

This paper studies profit shifting of German MNEs using newly available data from countryby-country reports for the years 2016 and 2017. We show that economic activities of German MNEs in tax havens are much more profitable than in non-havens. In addition, there is a strong negative correlation between effective average tax rates and revenues from intra-firm trade of goods and services. These findings support the view that German MNEs exploit opportunities to shift profits to tax havens. However, compared to the profits in non-haven countries, profits reported in tax havens are small - only accounting for $9 \%$ of global profits. According to our estimates, roughly $40 \%$ of the profits reported in tax havens are a result of tax-induced profit shifting. Large MNEs are more tax sensitive and therefore responsible for most of the profit shifting. In total, profit shifting by large German MNEs gives rise to an annual loss in tax revenue for German tax authorities of EUR 1.6 billion. Note that this excludes losses from profit shifting by German MNEs with revenues below EUR 750 million, and by the German subsidiaries of foreign MNEs. Adding estimates of profit shifting by firms not covered by the

$\mathrm{CbC}$ data leads to an overall estimate of EUR 5.7 billion per year in German tax revenue loss due to corporate profit shifting to tax havens.

In a recent paper, Tørsløv et al. (2018) report that globally, MNEs shift $40 \%$ of their foreign profits to tax haven countries. While we do find evidence for profit shifting, the volume we estimate based on our sample of large German MNEs is much smaller than the figure reported by Tørsløv et al. (2018). Our findings suggest that annually, EUR 3.8 billion of EUR 125 billion of total foreign profits of German MNEs are shifted to tax havens, yielding a share of approximately $3 \%$.

In general, estimates of the extent of profit shifting in the literature tend to be higher, although some studies, in particular Blouin and Robinson (2020), find similar magnitudes. The differences in the results may result from different methods or data sources, but they may also reveal that German MNEs are less prone to shift profits than MNEs from other countries. That in turn could reflect tighter anti-tax avoidance policies in Germany and in important host countries of German foreign investment. Another reason could be differences in profit shifting opportunities due to firm characteristics such as the importance of intangible assets. 


\section{References}

Auerbach, M. (2016). Toxic tax deals: When BASF's tax structure is more about style than substance. Study commissioned by the Greens/EFA Group in the European Parliament.

Beer, S., De Mooij, R. and Liu, L. (2020). International corporate tax avoidance: A review of the channels, magnitudes, and blind spots. Journal of Economic Surveys, 34 (3), 660-688.

Blouin, J. and Robinson, L. A. (2020). Double counting accounting: How much profit of multinational enterprises is really in tax havens? mimeo.

Buettner, T. and Wamser, G. (2013). Internal debt and multinational profit shifting: Empirical evidence from firm-level panel data. National Tax Journal, 66 (1), 63-96.

Clausing, K. (2016). The effect of profit shifting on the corporate tax base in the United States and beyond. National Tax Journal, 69 (4), 905-934.

Davies, R. B., Martin, J., Parenti, M. and Toubal, F. (2018). Knocking on tax haven's door: Multinational firms and transfer pricing. Review of Economics and Statistics, 100 (1), $120-134$.

Desai, M. A., Foley, C. F. and Hines, J. R. (2006). The demand for tax haven operations. Journal of Public Economics, 90 (3), 513-531.

Dharmapala, D. (2014). What do we know about base erosion and profit shifting? A review of the empirical literature. Fiscal Studies, 35 (4), 421-448.

Dischinger, M. and Riedel, N. (2011). Corporate taxes and the location of intangible assets within multinational firms. Journal of Public Economics, 95 (7-8), 691-707.

Dowd, T., Landefeld, P. and Moore, A. (2017). Profit shifting of US multinationals. Journal of Public Economics, 148, 1-13.

Dyreng, S. and Hanlon, M. (2020). Tax avoidance and multinational firm behavior. Forthcoming in: Multinational corporations in a changing global economy. International Tax Policy Forum, Washington, DC.

Feenstra, R. C., InklaAr, R. and Timmer, M. P. (2015). The next generation of the Penn World Table. American Economic Review, 105 (10), 3150-3182.

Fuest, C., Hebous, S. and Riedel, N. (2011). International debt shifting and multinational firms in developing economies. Economics Letters, 113 (2), 135-138.

Garcia-Bernardo, J., Jansky, P. et al. (2019). Multinational corporations and tax havens: Evidence from country-by-country reporting. IES Working Paper, 31. 
Griffith, R., Miller, H. and O'Connell, M. (2014). Ownership of intellectual property and corporate taxation. Journal of Public Economics, 112, 12-23.

Gumpert, A., Hines, J. R. and Schnitzer, M. (2016). Multinational firms and tax havens. Review of Economics and Statistics, 98 (4), 713-727.

Hanlon, M. (2018). Country-by-country reporting and the international allocation of taxing rights. Bulletin for International Taxation, $74(4 / 5)$.

Heckemeyer, J. H. and Overesch, M. (2017). Multinationals' profit response to tax differentials: Effect size and shifting channels. Canadian Journal of Economics, 50 (4), 965-994.

Hines, J. R. and Rice, E. M. (1994). Fiscal paradise: Foreign tax havens and American business. The Quarterly Journal of Economics, 109 (1), 149-182.

HugGer, F. (2020). The impact of country-by-country reporting on corporate tax avoidance. ifo Working Paper, 304.

HuizingA, H. and LAeven, L. (2008). International profit shifting within multinationals: A multi-country perspective. Journal of Public Economics, 92 (5-6), 1164-1182.

IMF (2016). Corporate taxation in the global economy. . IMF Policy Paper 19/00\%.

Johansson, A., Skeie, Ø. B., Sorbe, S. and Menon, C. (2017). Tax planning by multinational firms: Firm-level evidence from a cross-country database. OECD Economics Department Working Paper, 1355.

Kalemli-Ozcan, S., Sorensen, B., Villegas-Sanchez, C., Volosovych, V. and YesilTAS, S. (2015). How to construct nationally representative firm level data from the Orbis global database: New facts and aggregate implications. NBER Working Paper, 21558.

LAngenmayr, D. and Liu, L. (2020). Where does multinational profit go with territorial taxation? Evidence from the UK. CESifo Working Paper, 8047.

Menkhoff, L. and Miethe, J. (2019). Tax evasion in new disguise? Examining tax havens' international bank deposits. Journal of Public Economics, 176, 53-78.

Millimet, D. and Parmeter, C. (2019). Accounting for skewed or one-sided measurement error in the dependent variable. IZA Discussion Paper, $\mathbf{1 2 5 7 6 .}$

OECD (2017). BEPS Action 13 on country-by-country reporting. OECD Publishing, Paris.

Tørsløv, T. R., Wier, L. S. and Zucman, G. (2018). The missing profits of nations. NBER Working Paper, 24701. 
Wier, L. and Reynolds, H. (2018). Big and 'unprofitable': How $10 \%$ of multinational firms do $98 \%$ of profit shifting. WIDER Working Paper, 111.

Zucman, G. (2014). Taxing across borders: Tracking personal wealth and corporate profits. Journal of Economic Perspectives, 28 (4), 121-48. 


\section{Appendix}

Figure A1: Global distribution of German MNEs' assets

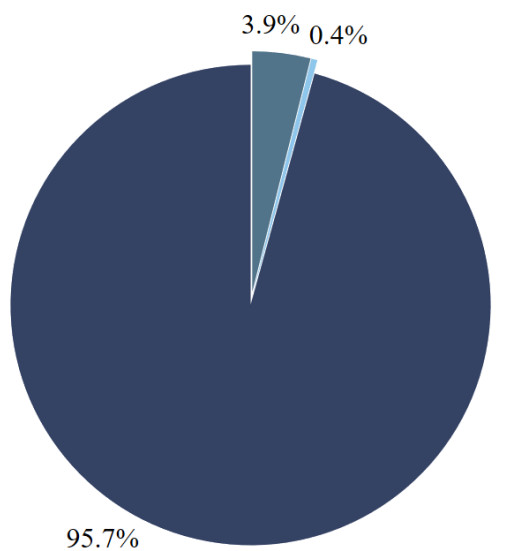

Non-havens

European tax havens

Non-European tax havens

Notes: This figure shows the average distribution of large German MNEs' total assets across country groups for the years 2016 and 2017 .

Figure A2: Global distribution of German MNEs' employees

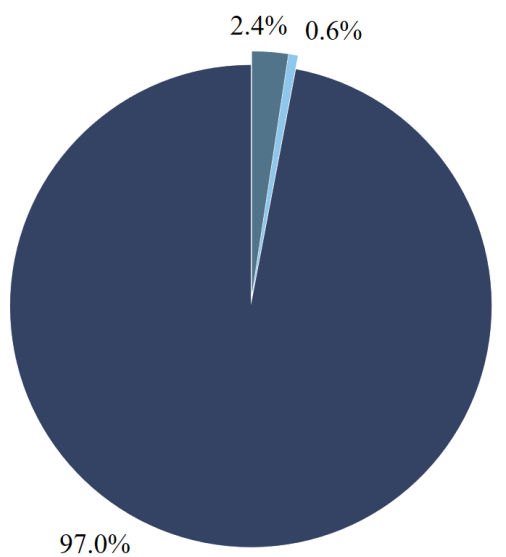

Non-havens

European tax havens

Non-European tax havens

Notes: This figure shows the average distribution of large German MNEs employees across country groups for the years 2016 and 2017. 
Table A1: Descriptive statistics for the CbC sample

\begin{tabular}{|c|c|c|c|c|c|c|c|c|c|}
\hline \multirow[b]{2}{*}{ Variable } & \multicolumn{3}{|c|}{$\begin{array}{l}\text { Complete } \\
\text { sample }\end{array}$} & \multicolumn{3}{|c|}{$\begin{array}{l}\text { European } \\
\text { tax havens }\end{array}$} & \multicolumn{3}{|c|}{$\begin{array}{l}\text { Non-European } \\
\text { tax havens }\end{array}$} \\
\hline & Obs & Mean & SD & Obs & Mean & SD & Obs & Mean & $\mathrm{SD}$ \\
\hline Log(Profits) & 9,465 & 14.69 & 2.668 & 717 & 15.24 & 2.653 & 362 & 14.53 & 2.465 \\
\hline Profits (in mio. EUR) & 9,465 & 57.61 & 474.7 & 717 & 57.71 & 225.6 & 362 & 16.37 & 40.05 \\
\hline Log(Intra-firm revenues) & 8,375 & 15.06 & 3.463 & 647 & 15.50 & 3.505 & 338 & 15.30 & 3.232 \\
\hline $\begin{array}{l}\text { Revenues related } \\
\text { (in mio. EUR) }\end{array}$ & 9,465 & 203.3 & $2,386.0$ & 717 & 128.8 & 483.4 & 362 & 123.2 & 759.5 \\
\hline Statutory tax rate & 9,410 & 0.245 & 0.075 & 717 & 0.214 & 0.057 & 358 & 0.163 & 0.050 \\
\hline Effective avg. tax rate & 9,275 & 0.194 & 0.095 & 717 & 0.104 & 0.020 & 345 & 0.110 & 0.053 \\
\hline $\begin{array}{l}\text { Statutory tax rate } \\
\text { (differential) }\end{array}$ & 9,397 & -0.044 & 0.081 & 717 & -0.075 & 0.061 & 358 & -0.133 & 0.063 \\
\hline $\begin{array}{l}\text { Effective avg. tax rate } \\
\text { (differential) }\end{array}$ & 9,262 & 0.033 & 0.098 & 717 & -0.054 & 0.029 & 345 & -0.050 & 0.059 \\
\hline $\log$ (Assets) & 9,465 & 15.37 & 3.187 & 717 & 15.22 & 3.347 & 362 & 14.51 & 2.794 \\
\hline Assets (in mio. EUR) & 9,465 & 284.3 & $3,406.0$ & 717 & 146.80 & $1,152.1$ & 362 & 31.38 & 133.3 \\
\hline Log(Employment) & 9,465 & 4.933 & 2.076 & 717 & 4.518 & 1.870 & 362 & 4.028 & 1.706 \\
\hline Employment & 9,465 & 1338.2 & $7,618.0$ & 717 & 429.3 & $1,042.5$ & 362 & 223.6 & 515.1 \\
\hline Log(Revenues unrelated) & 9,465 & 17.05 & 2.894 & 717 & 17.24 & 2.790 & 362 & 16.58 & 2.728 \\
\hline $\begin{array}{l}\text { Revenues unrelated } \\
\text { (in mio. EUR) }\end{array}$ & 9,465 & 444.48 & $3,004.1$ & 717 & 234.5 & 538.3 & 362 & 170.7 & 727.9 \\
\hline Corruption perception index & 9,465 & 0.598 & 0.192 & 717 & 0.807 & 0.072 & 362 & 0.764 & 0.136 \\
\hline Log(GDP per capita) & 9,465 & 10.27 & 0.706 & 717 & 10.99 & 0.252 & 362 & 10.94 & 0.586 \\
\hline Log(Population) & 9,465 & 3.314 & 1.597 & 717 & 1.859 & 1.180 & 362 & 1.519 & 1.012 \\
\hline
\end{tabular}


Table A2: List of tax havens

\begin{tabular}{ll}
\hline \hline Category & Countries \\
\hline European tax havens & Cyprus, Gibraltar, Ireland, Liechtenstein, Luxembourg, \\
& Malta, Netherlands, Switzerland \\
Non-European tax havens & Antigua and Barbuda, Bahamas, Bahrain, Barbados, Belize, Bermuda, \\
& British Virgin Islands, Cayman Islands, Cook Islands, Curacao, \\
& Gibraltar, Grenada, Guernsey, Hong Kong, Isle of Man, Jersey, Liberia, \\
& Montserrat, Panama, Saint Kitts and Nevis, Saint Vincent and the \\
& Grenadines, Singapore, Sint Maarten, Turks and Caicos Islands, Vanuatu \\
\hline \hline
\end{tabular}

Notes: The classification is based on IMF (2016) and Menkhoff and Miethe (2019).

Table A3: Descriptive statistics for the Orbis sample

\begin{tabular}{lccccccccc}
\hline \hline & \multicolumn{3}{c}{$\begin{array}{c}\text { Complete } \\
\text { sample }\end{array}$} & \multicolumn{3}{c}{$\begin{array}{c}\text { European } \\
\text { tax havens }\end{array}$} & $\begin{array}{c}\text { Non-European } \\
\text { tax havens }\end{array}$ \\
\cline { 2 - 8 } Variable & Obs. & Mean & SD & Obs & Mean & SD & Obs & Mean & SD \\
\hline Log(Profits) & 3,751 & 15.02 & 2.430 & 165 & 15.73 & 2.155 & 0 & - & - \\
Profits (in mio. EUR) & 3,751 & 67.42 & 387.6 & 165 & 93.48 & 357.1 & 0 & - & - \\
Statutory tax rate & 3,751 & 0.227 & 0.062 & 165 & 0.216 & 0.065 & 0 & - & - \\
Effective avg. tax rate & 3,713 & 0.198 & 0.073 & 164 & 0.067 & 0.048 & 0 & - & - \\
Statutory tax rate & 3,702 & -0.032 & 0.069 & 162 & -0.049 & 0.069 & 0 & - & - \\
(differential) & & & & & & & & & - \\
Effective avg. tax rate & 3,664 & -0.034 & 0.094 & 161 & -0.168 & 0.068 & 0 & - \\
(differential) & & & & & & & & - \\
Log(Assets) & 3,751 & 14.73 & 3.159 & 165 & 14.02 & 3.220 & 0 & - \\
Assets (in mio. EUR) & 3,751 & 121.0 & 839.1 & 165 & 22.91 & 162.8 & 0 & - \\
Log(Employment) & 3,751 & 5.146 & 2.018 & 165 & 4.612 & 1.522 & 0 & - & - \\
Employment & 3,751 & $1,377.3$ & $7,032.8$ & 165 & 265.9 & 407.3 & 0 & - & - \\
Log(Revenues) & 3,751 & 17.90 & 2.158 & 165 & 18.00 & 1.928 & 0 & - \\
Revenues (in mio. EUR) & 3,751 & $3,902.6$ & $198,749.2$ & 165 & 283.7 & 708.0 & 0 & - \\
Corruption perception index & 3,751 & 0.620 & 0.169 & 165 & 0.793 & 0.046 & 0 & - \\
Log(GDP per capita) & 3,751 & 10.42 & 0.421 & 165 & 11.06 & 0.281 & 0 & - \\
Log(Population) & 3,751 & 3.103 & 1.432 & 165 & 1.766 & 1.273 & 0 & - \\
\hline \hline
\end{tabular}


Table A4: Complete list of countries covered by $\mathrm{CbC}$ reports vs. Orbis

\begin{tabular}{|c|c|c|c|c|c|c|c|c|c|}
\hline \multirow{2}{*}{$\begin{array}{l}\text { Country } \\
\text { (ISO code) }\end{array}$} & \multicolumn{4}{|c|}{ Coverage of } & \multirow{2}{*}{$\begin{array}{l}\text { Country } \\
\text { (ISO Code) }\end{array}$} & \multicolumn{4}{|c|}{ Coverage of } \\
\hline & profits & assets & employment & entities & & profits & assets & employment & entities \\
\hline $\mathrm{AD}$ & 0 & - & - & 0 & $\mathrm{KZ}$ & 0 & 0 & 0 & 0 \\
\hline $\mathrm{AE}$ & 0 & 0 & 0 & 0 & LA & 0 & 0 & 0 & 0 \\
\hline $\mathrm{AF}$ & 0 & - & 0 & 0 & $\mathrm{LB}$ & 0 & 0 & 0 & 0 \\
\hline $\mathrm{AG}$ & - & - & - & 0 & LI & 0 & 0 & 0 & 0 \\
\hline $\mathrm{AL}$ & 0 & 0 & 0 & 0 & LK & 0 & 0 & 0 & 0 \\
\hline $\mathrm{AM}$ & 0 & 0 & 0 & 0 & $\mathrm{LR}$ & 0 & 0 & 0 & 0 \\
\hline $\mathrm{AO}$ & 0 & 0 & 0 & 0 & $\mathrm{LS}$ & 0 & 0 & 0 & 0 \\
\hline $\mathrm{AR}$ & 0 & 0 & 0 & 0 & $\mathrm{LT}$ & 77.7 & 29.4 & 48.6 & 27.3 \\
\hline $\mathrm{AT}$ & 45.4 & 27.8 & 63.0 & 67.3 & $\mathrm{LU}$ & 37.6 & 2.7 & 33.4 & 17.3 \\
\hline $\mathrm{AU}$ & 28.6 & 19.4 & 77.3 & 18.6 & LV & 108.5 & 23.9 & 61.9 & 47.5 \\
\hline AW & 0 & 0 & 0 & 0 & LY & - & 0 & 0 & 0 \\
\hline $\mathrm{AZ}$ & 0 & 0 & 0 & 0 & MA & 0 & 0 & 0 & 0 \\
\hline BA & 53.9 & 37.9 & 59.0 & 69.7 & $\mathrm{MC}$ & 0 & 0 & 0 & 0 \\
\hline $\mathrm{BB}$ & 0 & 0 & 0 & 0 & MD & 0 & 0 & 0 & 0 \\
\hline $\mathrm{BD}$ & 0 & 0 & 0 & 0 & $\mathrm{ME}$ & 101.6 & 94.5 & 57.2 & 66.7 \\
\hline $\mathrm{BE}$ & 64.0 & 43.0 & 71.9 & 56.6 & MG & 0 & 0 & 0 & 0 \\
\hline $\mathrm{BF}$ & 0 & 0 & 0 & 0 & $\mathrm{MH}$ & 0 & 0 & - & 0 \\
\hline BG & 65.9 & 55.3 & 96.4 & 59.6 & MK & 83.9 & 87.2 & 107.2 & 37.5 \\
\hline $\mathrm{BH}$ & 0 & 0 & 0 & 0 & ML & 0 & 0 & 0 & 0 \\
\hline BI & 0 & 0 & 0 & 0 & $\mathrm{MM}$ & 0 & 0 & 0 & 0 \\
\hline BJ & 0 & 0 & 0 & 0 & $\mathrm{MN}$ & 0 & 0 & 0 & 0 \\
\hline $\mathrm{BM}$ & 0 & 0 & 0 & 0 & $\mathrm{MO}$ & 0 & 0 & 0 & 0 \\
\hline $\mathrm{BN}$ & 0 & 0 & 0 & 0 & $\mathrm{MQ}$ & 0 & 0 & 0 & 0 \\
\hline $\mathrm{BO}$ & 0 & 0 & 0 & 0 & MR & 0 & 0 & 0 & 0 \\
\hline $\mathrm{BR}$ & 26.5 & 4.3 & 2.6 & 5.7 & MT & 0.0 & 0.0 & 0.8 & 2.7 \\
\hline BS & 0 & 0 & 0 & 0 & $\mathrm{MU}$ & 0 & 0 & 0 & 0 \\
\hline BW & 0 & 0 & 0 & 0 & MW & - & 0 & 0 & 0 \\
\hline BY & 0 & 0 & 0 & 0 & MX & 0.5 & 0.2 & 0.3 & 0.3 \\
\hline $\mathrm{BZ}$ & 0 & 0 & 0 & 0 & MY & 0 & 0 & 0 & 0 \\
\hline $\mathrm{CA}$ & 0 & 0 & 0 & 0 & $\mathrm{MZ}$ & - & 0 & 0 & 0 \\
\hline $\mathrm{CD}$ & 0 & 0 & 0 & 0 & NA & 0 & 0 & 0 & 0 \\
\hline $\mathrm{CF}$ & 0 & 0 & 0 & 0 & $\mathrm{NC}$ & 0 & 0 & 0 & 0 \\
\hline $\mathrm{CG}$ & 0 & 0 & 0 & 0 & $\mathrm{NE}$ & 0 & 0 & 0 & 0 \\
\hline $\mathrm{CH}$ & 0 & 0 & 0 & 0 & NG & 0 & 0 & 0 & 0 \\
\hline CI & 0 & 0 & 0 & 0 & $\mathrm{NI}$ & 0 & 0 & 0 & 0 \\
\hline CL & 0 & 0 & 0 & 0 & NL & 47.9 & 7.9 & 16.4 & 29.3 \\
\hline $\mathrm{CM}$ & 0 & 0 & 0 & 0 & $\mathrm{NO}$ & 96.8 & 134.7 & 106.2 & 75.9 \\
\hline $\mathrm{CN}$ & 51.5 & 18.9 & 44.1 & 21.6 & NP & 0 & 0 & 0 & 0 \\
\hline $\mathrm{CO}$ & 0 & 0.002 & 0.01 & 1.1 & $\mathrm{NZ}$ & 0 & 0 & 0 & 0 \\
\hline $\mathrm{CR}$ & 0 & 0 & 0 & 0 & $\mathrm{OM}$ & 0 & 0 & 0 & 0 \\
\hline $\mathrm{CU}$ & - & 0 & 0 & 0 & $\mathrm{PA}$ & 0 & 0 & 0 & 0 \\
\hline $\mathrm{CV}$ & 0 & 0 & 0 & 0 & $\mathrm{PE}$ & 10.2 & 0.6 & 4.7 & 1.6 \\
\hline CW & 0 & 0 & 0 & 0 & $\mathrm{PF}$ & 0 & 0 & 0 & 0 \\
\hline $\mathrm{CY}$ & 0 & 0 & 0 & 0 & PG & 0 & 0 & 0 & 0 \\
\hline $\mathrm{CZ}$ & 51.5 & 46.6 & 64.2 & 76.0 & $\mathrm{PH}$ & 0 & 0 & 0 & 0 \\
\hline $\mathrm{DE}$ & 62.0 & 19.6 & 43.7 & 39.5 & PK & 0 & 0 & 0 & 0 \\
\hline DK & 59.5 & 31.0 & 56.0 & 44.1 & PL & 42.8 & 24.1 & 45.8 & 50.0 \\
\hline DO & 0 & 0 & 0 & 0 & PR & 0 & 0 & 0 & 0 \\
\hline $\mathrm{DZ}$ & 0 & 0 & 0 & 0 & PS & - & 0 & 0 & 0 \\
\hline $\mathrm{EC}$ & 0 & 0 & 0 & 0 & $\mathrm{PT}$ & 68.4 & 26.4 & 57.4 & 70.7 \\
\hline $\mathrm{EE}$ & 43.6 & 34.6 & 42.9 & 46.7 & PY & 0 & 0 & 0 & 0 \\
\hline EG & 0 & 0 & 0 & 0 & QA & 0 & 0 & 0 & 0 \\
\hline ES & 44.4 & 45.1 & 67.5 & 62.9 & $\mathrm{RE}$ & 0 & 0 & 0 & 0 \\
\hline $\mathrm{ET}$ & 0 & 0 & 0 & 0 & $\mathrm{RO}$ & 77.9 & 64.0 & 66.5 & 61.4 \\
\hline FI & 99.1 & 18.7 & 57.3 & 44.4 & $\mathrm{RS}$ & 105.3 & 55.6 & 80.1 & 73.4 \\
\hline
\end{tabular}


Table A2.4 continued

\begin{tabular}{|c|c|c|c|c|c|c|c|c|c|}
\hline \multirow{2}{*}{$\begin{array}{l}\text { Country } \\
\text { (ISO code) }\end{array}$} & \multicolumn{4}{|c|}{ Coverage of } & \multirow{2}{*}{$\begin{array}{l}\text { Country } \\
\text { (ISO Code) }\end{array}$} & \multicolumn{4}{|c|}{ Coverage of } \\
\hline & profits & assets & employment & entities & & profits & assets & employment & entities \\
\hline FJ & 0 & 0 & 0 & 0 & $\mathrm{RU}$ & 101.0 & 36.5 & 67.0 & 64.1 \\
\hline FM & 0 & 0 & 0 & 0 & RW & 0 & 0 & 0 & 0 \\
\hline FR & 91.2 & 20.3 & 72.2 & 54.9 & SA & 0 & 0 & 0 & 0 \\
\hline GA & - & 0 & 0 & 0 & SB & 0 & 0 & 0 & 0 \\
\hline UK & 73.0 & 49.7 & 103.3 & 74.2 & $\mathrm{SE}$ & 10.1 & 56.3 & 54.5 & 52.5 \\
\hline GE & 0 & 0 & 0 & 0 & $\mathrm{SG}$ & 0 & 0 & 0 & 0 \\
\hline GF & - & - & 0 & 0 & SI & 79.1 & 39.5 & 70.4 & 65.9 \\
\hline GG & 0 & 0 & 0 & 0 & SK & 47.1 & 34.9 & 36.8 & 47.5 \\
\hline GH & 0 & 0 & 0 & 0 & $\mathrm{SL}$ & 0 & 0 & 0 & 0 \\
\hline GI & 0 & - & - & 0 & $\mathrm{SM}$ & 0 & 0 & 0 & 0 \\
\hline GM & 0 & 0 & 0 & 0 & $\mathrm{SN}$ & 0 & 0 & 0 & 0 \\
\hline GN & 0 & 0 & 0 & 0 & $\mathrm{SV}$ & 0 & 0 & 0 & 0 \\
\hline GP & 0 & 0 & 0 & 0 & SX & - & 0 & 0 & 0 \\
\hline GQ & 0 & 0 & 0 & 0 & SY & 0 & 0 & 0 & 0 \\
\hline GR & 14.3 & 4.3 & 17.8 & 34.2 & $\mathrm{SZ}$ & 0 & 0 & 0 & 0 \\
\hline GT & 0 & 0 & 0 & 0 & $\mathrm{TD}$ & 0 & 0 & 0 & 0 \\
\hline GW & 0 & 0 & 0 & 0 & TG & 0 & 0 & 0 & 0 \\
\hline HK & 0 & 0 & 0 & 0 & $\mathrm{TH}$ & 0 & 0 & 0 & 0 \\
\hline $\mathrm{HN}$ & 0 & 0 & 0 & 0 & TJ & - & 0 & 0 & 0 \\
\hline HR & 84.5 & 64.8 & 85.6 & 64.9 & $\mathrm{TL}$ & 0 & 0 & - & 0 \\
\hline $\mathrm{HT}$ & - & 0 & 0 & 0 & $\mathrm{TM}$ & - & 0 & 0 & 0 \\
\hline $\mathrm{HU}$ & 36.0 & 45.8 & 53.1 & 39.8 & $\mathrm{TN}$ & 0 & 0 & 0 & 0 \\
\hline ID & 0 & 0 & 0 & 0 & TO & - & - & - & 0 \\
\hline IE & 65.8 & 2.1 & 67.6 & 111.4 & $\mathrm{TR}$ & 0.6 & 0.2 & 0.9 & 0.8 \\
\hline IL & 0 & 0 & 0 & 0 & $\mathrm{TT}$ & 0 & 0 & 0 & 0 \\
\hline IM & 0 & - & - & 0 & TW & 38.0 & 6.7 & 48.7 & 1.4 \\
\hline IN & 0.1 & 0.9 & 1.0 & 4.7 & $\mathrm{TZ}$ & 0 & 0 & 0 & 0 \\
\hline IQ & 0 & 0 & 0 & 0 & UA & 77.1 & 37.9 & 77.0 & 35.3 \\
\hline IR & 0 & 0 & 0 & 0 & UG & 0 & 0 & 0 & 0 \\
\hline IS & 56.5 & 51.5 & 86.9 & 75.0 & US & 0 & 0 & 0 & 0 \\
\hline IT & 41.0 & 23.3 & 51.9 & 72.3 & UY & 0 & 0 & 0 & 0 \\
\hline $\mathrm{JE}$ & 0 & 0 & 0 & 0 & $\mathrm{UZ}$ & 0 & 0 & 0 & 0 \\
\hline $\mathrm{JM}$ & - & 0 & 0 & 0 & $\mathrm{VE}$ & 0 & 0 & 0 & 0 \\
\hline JO & 0 & 0 & 0 & 0 & VG & 0 & 0 & 0 & 0 \\
\hline $\mathrm{JP}$ & 1.5 & 0.6 & 1.8 & 3.5 & VI & 0 & 0 & 0 & 0 \\
\hline $\mathrm{KE}$ & 0 & 0 & 0 & 0 & $\mathrm{VN}$ & 0 & 0 & 0 & 0 \\
\hline $\mathrm{KG}$ & - & - & - & 0 & WS & 0 & - & - & 0 \\
\hline KH & 0 & 0 & 0 & 0 & XK & 0 & 0 & 0 & 0 \\
\hline KP & 0 & 0 & 0 & 0 & $\mathrm{ZA}$ & 0 & 0 & 0 & 0 \\
\hline $\mathrm{KR}$ & 48.8 & 7.8 & 52.9 & 30.3 & $\mathrm{ZM}$ & 0 & 0 & 0 & 0 \\
\hline KW & 0 & 0 & 0 & 0 & ZW & 0 & 0 & 0 & 0 \\
\hline KY & 0 & 0 & 0 & 0 & & & & & \\
\hline
\end{tabular}

Notes: This table shows the coverage of $\mathrm{CbC}$ data by Orbis (in \%). The figures represent the ratio of the respective variable's realization in Orbis to its realization in the $\mathrm{CbC}$ data. "-" indicates that the variable is zero in the $\mathrm{CbC}$ data. 